SONIA I. OCAÑA RUIZ

\title{
Nuevas reflexiones sobre las pinturas incrustadas de concha y el trabajo de Juan y Miguel González
}

$\mathrm{D}$ ESDE PRINCIPIOS DEL SIGLO XX, el estudio de las pinturas incrustadas de concha ( $c a$. I650-I750) se ha ligado a Miguel y, en menor medida, a Juan González, artistas de los que se sabe poco, pero cuya importancia en relación con estas obras es difícil sobrestimar. Ambos trabajaron en la ciudad de México a finales del siglo XVII y principios del XVIII. Su producción fue nutrida, pues entre los dos firmaron cerca de la tercera parte de las más de 250 obras que se conocen. ${ }^{\text {I }}$ Como se verá adelante, algunas de las aproximadamente I6o tablas anónimas que se conservan asimismo deben ser suyas. Si bien ciertos autores han creído que fueron hermanos, ${ }^{2}$

I. Tanto las obras de Miguel González como las de su pariente Juan González se listan en el "Apéndice" de este artículo.

2. Virginia Armella de Aspe, "La influencia asiática", en La concha nácar en México, México, Grupo Gutsa, I990, p. 72; Teresa Castelló, "Los artesanos artistas", en La concha..., op. cit., pp. I40-I42; Rodrigo Rivero Lake, La visión de un anticuario, México, Américo Arte, I997, p. 246; El arte namban en el México virreinal, Madrid, Turner, 2005; Guillermo Tovar de Teresa, "Documentos sobre 'enconchados' y la familia mexicana de los González", Cuadernos de Arte Colonial, Museo de América, núm. I, 1986, p. Ioo; Marita Martínez del Río de Redo, "La conquista en una serie de tablas enconchadas", en Imágenes de los naturales en el arte de la Nueva España. Siglos XVI al XVIII, México, Fomento Cultural Banamex/Universidad Nacional Autónoma de México-Instituto de Investigaciones Estéticas/Dirección General de Asuntos del Personal Académico, p. 66; Gabriela García Lascurain Vargas, "Noticias acerca 
en realidad no fue así, aunque sin duda ambos pintores estuvieron emparentados. ${ }^{3}$

$\mathrm{Al}$ menos dos generaciones de los González se involucraron en las pinturas incrustadas de concha, pues un documento de 1689 se refiere a Tomás González de Villaverde, "maestro de pintor de maque", y a Miguel, su hijo mayor de 25 años, "oficial de dicho arte de pintor". ${ }^{4}$ Así pues, el padre de Miguel González, de quien la única información que existe aparece en dicho documento y en otro del mismo año, también se dedicó a este tipo de pinturas, probablemente a partir de 1660.5 Téngase en cuenta que las ordenanzas del gremio de pintores se publicaron por primera vez en I557 y nuevamente en I686. Es decir, tanto Tomás como Miguel González se acreditaron ante dicho gremio poco después de reformularse las ordenanzas que lo rigieron. Por otro lado, la locución "pintor de maque" — esto es, pintor de laca- es digna de atención y se comentará más adelante. ${ }^{6}$

No sorprende que en ocasiones se haya creído en la supuesta relación fraternal entre Miguel y Juan González, pues ambos trabajaron en la última década del siglo XVII, cuando las pinturas incrustadas de concha alcanzaron su apogeo. En su mayoría, las obras firmadas y fechadas de Juan González datan de 1697-1703, mientras que las de Miguel González corresponden a 1692-1698.7 Ahora bien, ambos firmaron algunas obras que no dataron y a menudo dejaron sus trabajos sin firmar, como hicieron numerosos pintores de la época.

La actividad de Juan González en realidad empezó hacia I662, cuando firmó una Natividad que pertenece a la Smithsonian Institution de Washington, D.C. (fig. I). De ahí la afirmación de que no fue hermano de Miguel González, quien probablemente habría nacido cuando Juan inició su producción artística. Quizá este último haya sido hermano de Tomás González, aunque de momento no es posible demostrarlo. ${ }^{8}$

de pinturas y pintores de enconchados en Oaxaca”, Anales del Instituto de Investigaciones Estéticas, vol. XXXIII, núm. 98, primavera de 201 I, p. 254, n. 6.

3. La posibilidad de que Juan González sea tío y no hermano de Miguel González fue advertida por María Concepción García Sáiz, "Precisiones al estudio de la obra de Miguel González", en Coloquio Internacional Extraordinario. Manuel Toussaint. Su proyección en la historia del arte mexicano, México, Universidad Nacional Autónoma de México-Instituto de Investigaciones Estéticas, I992, pp. I09-I Io. Véase también Julieta Ávila, "Juan y Miguel, los González de los enconchados no eran hermanos”, Boletín del INAH, núm. 40, I992, pp. 80-8I.

4. Tovar de Teresa, op. cit., p. IoI.

5. Hasta ahora no se conocen obras firmadas por este artista.

6. Véase pp. I33-I34.

7. Véase el "Apéndice".

8. El segundo apellido de Juan González fue De Mier, mientras que Tomás se apellidaba 


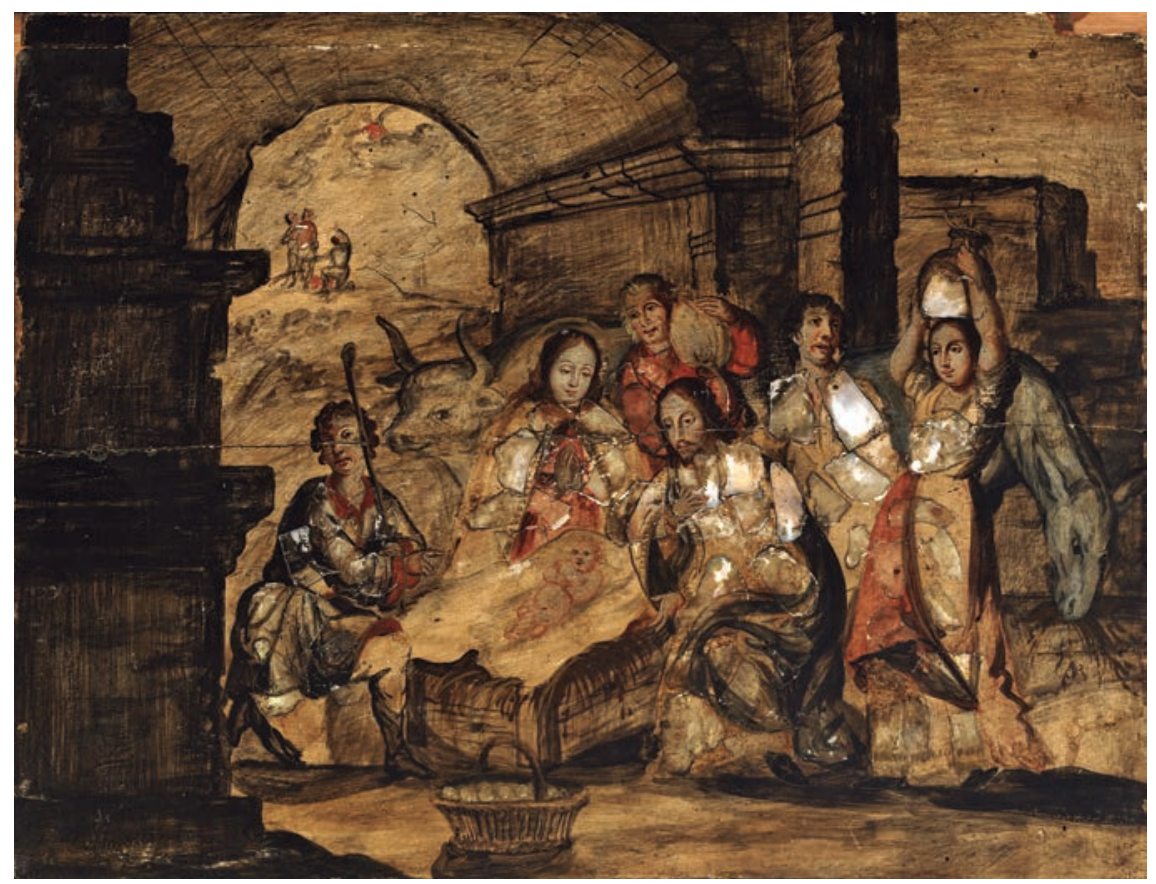

I. Juan González, Natividad, I662, ¿̨óleo y temple? e incrustaciones de concha nácar sobre tabla, $32.5 \times 4 \mathrm{I}$ cm, Smithsonian American Art Museum.

Tanto el origen como el apogeo de estas pinturas están ligados a los González, pero desde 1959 se sabe que también otros pintores incursionaron en ellas. ${ }^{9}$ Lamentablemente se conservan escasos ejemplares firmados. De Nicolás Correa, sobrino del prestigioso pintor Juan Correa, se conocen tres obras, ${ }^{10}$ lo mismo que de Agustín del Pino. ${ }^{\text {II }}$ Asimismo, Pedro López Calderón y un

González de Villaverde. Cfr. Tovar de Teresa, op. cit., pp. Ioo-ıoı. Esto podría indicar que no fueron hermanos, o al menos no de madre. Sin embargo, en tiempos virreinales las reglas para fijar los apellidos eran flexibles, por lo que Tomás y Juan bien podrían haber sido hijos de los mismos padres. En cualquier caso, está claro que fueron parientes y pertenecieron a la misma generación.

9. Martín Soria, "Painting in Spanish America", en Art and Architecture in Spain and Portugal and their American Dominions, I500-1800, Baltimore, Penguin Books, I959, p. 313.

Io. Véase el "Apéndice".

I I. En realidad sólo se conservan dos obras firmadas por Pino. Se trata de una Virgen de 
misterioso Rodulpho firmaron sendos ejemplares. ${ }^{\text {I2 }}$ Quizá también Antonio de Santander, activo en Puebla, haya hecho algunas obras. ${ }^{13}$ Se sabe poco de estos artistas. Ahora bien, al menos Correa y López Calderón incursionaron tanto en las pinturas con incrustaciones de concha como en las que prescindieron de ese material. ${ }^{I 4}$ Más aún, pertenecieron a generaciones distintas: el primero estuvo activo hacia 1690-I705 y el segundo hacia I720-I730. Es decir, esta producción tuvo cierta importancia en el contexto pictórico novohispano. Al margen de la incrustación de concha nácar, en las obras usaron los materiales y procedimientos acostumbrados en los talleres de pintura de la época. ${ }^{\text {I5 }}$

Guadalupe y un San Ignacio de Loyola, pero hay consenso respecto a su autoría de la tercera, pues es un San Francisco Xavier cuyas medidas y tratamiento iguales al San Ignacio de Loyola permiten afirmar que se trata de un encargo conjunto. Véase el "Apéndice".

I2. Véase el "Apéndice".

I3. Al respecto, la única noticia existente es de Martín Soria, quien en 1952 señaló que en la colección de Ramón Aranda había una Virgen de Balvanera de dicho artista. Sin embargo, en I990 se cuestionó que se tratara de una pintura incrustada de concha. C fr. Armella de Aspe, op. cit., p. 83, y Tovar de Teresa, "Los artistas y las pinturas con incrustaciones de concha nácar en México", en La concha nácar..., op. cit., p. I20. Recientemente la posibilidad de que Santander haya hecho este tipo de pinturas fue retomada por García Lascurain Vargas, op. cit., pp. 258-262.

I4. Nicolás Correa firmó, además de las tres pinturas incrustadas de concha mencionadas en el "Apéndice", una Multiplicación de los panes y los peces (Museo de América), unos Desposorios misticos de santa Rosa de Lima (Museo Nacional de Arte) y una Virgen del Rosario y santo Domingo de Guzmán (Museo Regional de Querétaro), que prescinden de dicho material. Respecto a Pedro López Calderón, véase María Concepción García Sáiz y Juan Miguel Serrera, "Aportaciones al catálogo de enconchados", Cuadernos de Arte Colonial, Madrid, Museo de América, núm. 6, I990, pp. 66-70. Según José Bernardo Couto, en un claustro alto del convento de San Fernando se hallaba, junto a la puerta de entrada de la sala de recibir, una obra firmada por Pedro López Calderón en 1728, que consideró de mediano mérito. Cfr. Diálogo sobre la historia de la pintura en México, México, Fondo de Cultura Económica, 2006 [ [ ${ }^{\text {a }}$ edición, I889], p. 73. De López Calderón se conserva un retrato del arzobispo Manuel Rubio y Salinas, de I754. Podría tratarse del mismo artista aquí mencionado, pero no conozco la firma de dicho retrato, así que de momento no puedo hacer afirmaciones al respecto. Véase una imagen de la obra en http://www.artnet.com/; consultada el Io de enero de 20I2. Por otro lado, este artista podría haber trabajado en Oaxaca. Cfr. García Lascurain Vargas, op. cit., p. 264.

I5. Al respecto véase, por ejemplo, José de Santiago, Algunas consideraciones sobre las pinturas enconchadas del Museo Nacional de Historia, México, Instituto Nacional de Antropología e Historia, 1976, así como Alejandro Huerta, Análisis de la técnica y material de dos colecciones de pinturas enconchadas, México, Instituto Nacional de Antropología e Historia (Textos Básicos y Manuales), 1991; Estefanía Rivas, "El empleo de la concha nácar en la pintura virreinal: 
Así pues, entre las numerosísimas obras anónimas que se conservan debe haber ejemplares de artistas cuyos nombres desconocemos. Al respecto, téngase en cuenta que la información documental demuestra la diversificación de los precios y, aunque la producción parece haberse concentrado en la ciudad de México, las obras circularon en otras ciudades. ${ }^{16}$

Dada la importancia de la producción de los González, he decidido dedicar este texto principalmente a ellos, con la idea de ampliar más adelante el análisis a otros artistas. Desde luego, el hecho de que apenas se conserven obras firmadas por otros pintores hace difícil determinar las características de su trabajo. Cabe esperar que futuras investigaciones técnicas proporcionen una idea más precisa sobre el procedimiento empleado en el mayor número posible de obras, lo cual contribuiría al estudio de las autorías.

\section{El trabajo de los González y su relación con el gremio de pintores}

Este texto estudiará en primer lugar algunas obras firmadas por Juan González y enseguida otras de Miguel González. Después se abordará una serie de la Conquista de México firmada por ambos en I698, que se conserva en el Museo de América de Madrid, y a continuación una obra anónima conservada en Sevilla, cuyas características permiten atribuirla a Miguel González. Finalmente, se comentarán una serie de la Vida de Cristo y dos de la Vida de la Virgen, todas anónimas, del Museo de América, cuyas características corresponden al trabajo de los González. Pese a tratarse de un número limitado de ejemplares, su factura heterogénea permitirá advertir la riqueza del trabajo de estos pintores, que no ha sido suficientemente estudiada.

Tanto Miguel como Juan González emplearon a menudo grabados europeos de raigambre manierista, a los que introdujeron deliberadas variaciones. Esto es, al margen del uso de la concha, ambos tomaron muy en serio el trabajo

estudio radiográfico de la colección de pintura 'enconchada' del Museo de América de Madrid”, Espacio, Tiempo y Forma, serie VII, Historia del Arte, t. I5, 2002, pp. I47-I67; Adelina Illán y Rafael Romero, "La técnica pictórica de los enconchados mexicanos y la problemática de su restauración", Ciencia y Esencia. Cuadernos de Conservación y Tecnología del Arte, núm. I, 2008, pp. 29-46.

I6. Véase Sonia I. Ocaña Ruiz, "Marcos enconchados: autonomía y apropiación de formas japonesas en la pintura novohispana”, Anales del Instituto de Investigaciones Estéticas, vol. XXX, núm. 92, primavera de 2008, p. 139. 
pictórico, ${ }^{17}$ en el que deben haberse involucrado de manera directa, pues de lo contrario difícilmente habrían podido encabezar sus propios talleres de pintura.

Numerosas obras de los González muestran el nácar incrustado en trozos irregulares relativamente pequeños que no conforman la totalidad de las vestiduras de los personajes (figs. 2 y Io). Los ejemplares más destacados exhiben ricos efectos lumínicos, distintos a los de otras pinturas. A menudo la técnica pictórica es más esmerada en las áreas que cubren la concha, lo cual sugiere que esa parte del trabajo correspondió a los González. Es probable que otros miembros del taller hayan cortado, pulido y pegado las conchas, algo ajeno a otros talleres de pintura.

Conviene subrayar que Nicolás Correa, activo en la misma época de los González, hizo obras notables, de características distintas a las de ellos. ${ }^{18}$ Así pues, los González no fueron los únicos pintores destacados que dedicaron una parte significativa de su trabajo a las pinturas incrustadas de concha. De ahí la afirmación de que no todos los ejemplares existentes bien logrados son de aquéllos. Aquí no pretendo agotar el estudio del estilo de los González ni apresurarme a atribuirles los numerosos ejemplares anónimos de buena factura que se conservan, pues la heterogeneidad de su trabajo exige mucha cautela a la hora de hacer atribuciones. En cambio, intentaré determinar, mediante el estudio de un número limitado de ejemplares, tanto firmados como anónimos, qué características del trabajo de Juan y de Miguel González tienden a permanecer constantes y cuáles muestran mayores variaciones, así como hasta qué punto existen similitudes entre las obras de ambos.

Es bien sabido que la clasificación estilística posee limitaciones, pues tiende a encasillar el trabajo de los artistas. ${ }^{19}$ Como se verá, tanto Miguel como Juan González escapan de dicho encasillamiento y ahí reside, en parte, el interés de sus obras. Ambos destacan por su capacidad para crear obras origina-

I7. Véase García Sáiz, "Precisiones al estudio...", op. cit., y "Nuevos materiales para nuevas expresiones", en Los siglos de oro en los virreinatos de América I550-I700, Madrid, Sociedad Estatal para la Conmemoración de los Centenarios de Felipe II y Carlos V, I999, pp. I27-I39.

I8. El tema se comenta más adelante. Véase pp. I34-I35.

19. Esto han advertido numerosos autores en los últimos ańos. Para el caso de la pintura novohispana véase Jonathan Brown, "La pintura en Sevilla y en la ciudad de México I560-I660: influencias y diferencias", en Juana Gutiérrez Haces (coord.), Pintura de los reinos. Identidades compartidas, territorios del mundo hispánico siglos XVI-XVIII, t. IV, México, Fomento Cultural Banamex, 2009, pp. 925-962. 


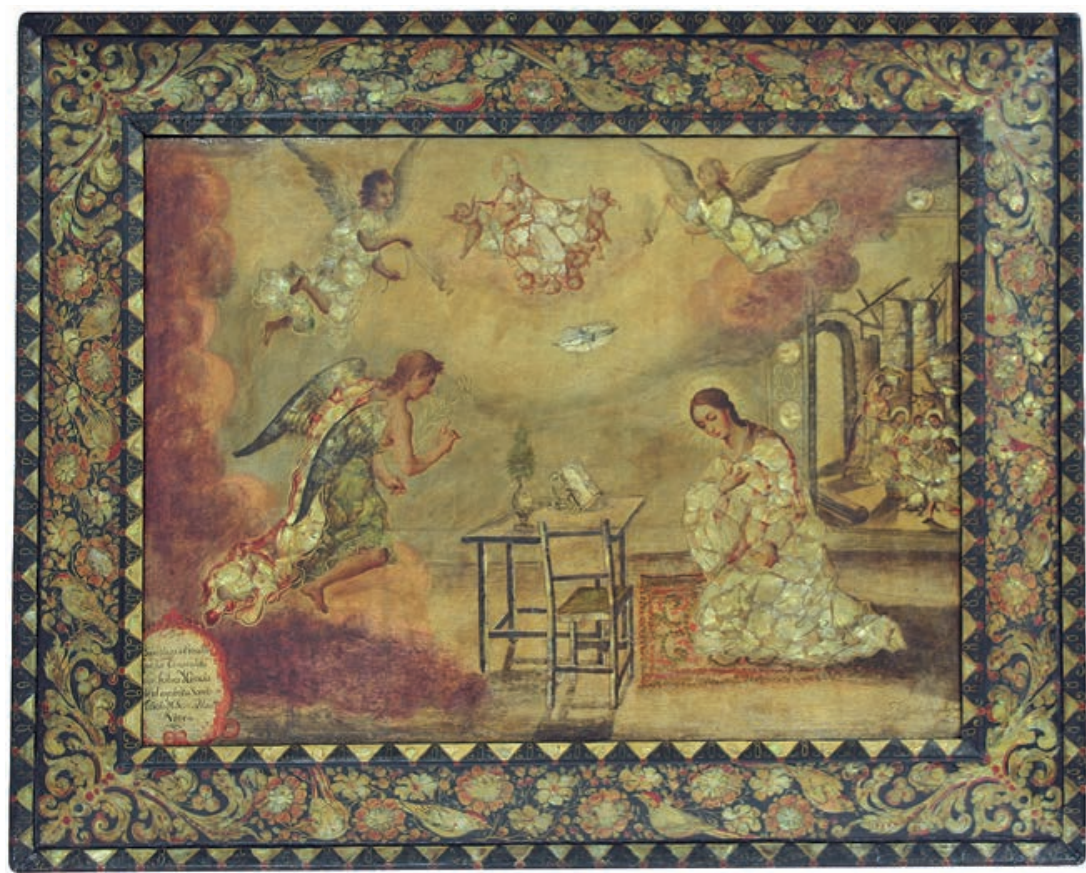

2a) Miguel González, Santiago el Mayor, de la serie Alegorías del Credo, finales del siglo XVII-principios del siglo XVIII, óleo, temple e incrustaciones de concha nácar sobre tabla, 6I × $86 \mathrm{~cm}$, Museo Nacional del Virreinato, Tepotzotlán; b) detalle. Foto: Sonia Ocaña.

Conaculta-INAH-MÉx. "Reproducción autorizada por el Instituto Nacional de Antropología e Historia”.

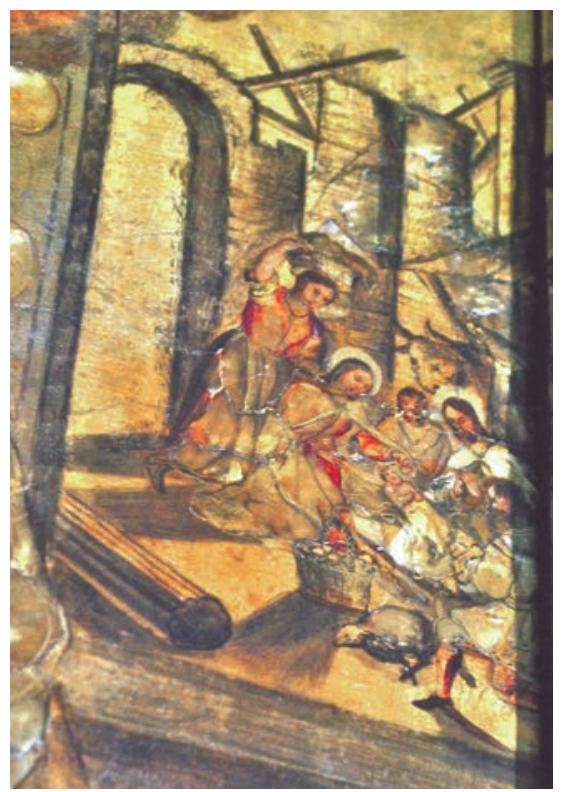


les a pesar de que a menudo basan sus composiciones en modelos. ${ }^{20}$ Con frecuencia Miguel González introduce cambios ya sea en la composición o en las figuras, mientras que Juan tiende a usar una paleta contrastada ${ }^{2 \mathrm{I}}$ y a incluir recursos lumínicos y ornamentales para enriquecer detalles como las vestiduras de los personajes. Numerosos ejemplares exhiben ricos marcos, que suelen tener articulación técnica, cromática e incluso iconográfica con las escenas representadas (figs. 3, 7, II-I 4 y I8). Como ya antes he estudiado los marcos de manera particular, en este texto sólo los abordaré en los casos en que me parece indispensable, pues en ocasiones ofrecen claves sobre la autoría de los ejemplares anónimos.

Aquí exploraré la posibilidad de que Juan y Miguel González hayan sido considerados especialistas en las pinturas incrustadas de concha. No se trata del tipo de especialización que se produjo en Europa después del Renacimiento, cuando algunos artistas tuvieron éxito al dedicarse exclusivamente a representar ciertos temas, ya fuesen retratos, paisajes, naturalezas muertas $\mathrm{u}$ otros. ${ }^{22}$ En el caso que nos ocupa, probablemente el gremio novohispano de pintores avaló el trabajo de los González, aunque sólo se dedicaran a este tipo de pinturas.

Se conocen cuatro documentos comprobatorios de que tanto Tomás como Miguel y Juan González pertenecieron a dicho gremio. ${ }^{23}$ De especial interés resulta un "Donativo del gremio de pintores y doradores para la Guerra de Sucesión” de la ciudad de México de 1704 que menciona a Miguel González entre los oficiales con tienda, llamándolo "el conchero". ${ }^{24}$ Las ordenanzas

20. García Sáiz ha señalado que tanto Juan como Miguel González “trabajan fundamentalmente a partir de grabados manieristas de principios del siglo XVII, de los que toman el gusto por las figuras inestables, de proporciones sumamente alargadas y posturas forzadas, situadas a menudo en primer término, de espaldas al espectador". García Sáiz, "Nuevos materiales...", op. cit., p. $\mathrm{I} 38$.

2. Ibidem, p. I39.

22. En el caso europeo, uno de los ejemplos más conocidos es el de Rubens y Jan Brueghel el Viejo, que trabajaron juntos en numerosas obras. Sobre este tema, véase el catálogo Rubens and Brueghel: A Working Friendship, Los Ángeles, Getty Publications (J. Paul Getty Museum Series), 2006.

23. Véase Tovar de Teresa, op. cit., pp. Iог-Io3, así como Paula Mues, La libertad del pincel. Los discursos sobre la nobleza de la pintura en la Nueva España, México, Universidad Iberoamericana-Departamento de Arte, 2008, p. 395.

24. Mues, op. cit. Es el único caso en dicho documento donde se usa ese término para referirse a un artista. Esto es significativo, pues el “Donativo” también menciona a Nicolás Correa. 
del gremio de pintores no se refieren ni al trabajo de los "concheros" ni al de "pintura de maque", empleado en un documento ligado a Tomás González. ${ }^{25}$ Ahora bien, tanto Tomás como Miguel y Juan González pertenecieron a dicho gremio. Es decir, los pintores de la época reconocieron que el trabajo de los González tenía una relación muy estrecha con el suyo.

El uso de los términos "pintura de maque", en relación con las obras que nos ocupan, fue excepcional. ${ }^{26}$ Más aún, técnicamente dichas obras no se relacionan con las lacas asiáticas ni con las novohispanas. ${ }^{27}$ Conviene añadir que se conserva un contrato (finalmente cancelado) de I699 celebrado por Juan González de Mier, "maestro de pintor", quien se comprometió a hacer algunas pinturas embutidas esto es, incrustadas (de concha) para cierto comitente. El documento no sólo omite referirse al maque, sino que concede mucha importancia al trabajo pictórico, al margen del uso de la concha. ${ }^{28}$ Las pinturas incrustadas de concha emplean la técnica y las concepciones pictóricas europeas, apropiándose a la vez las incrustaciones de dicho material y la ornamentación de las lacas japonesas de exportación del periodo I570-I630 que la historiografía ha denominado namban. ${ }^{29}$ Así pues, lo más probable es que el ocasional empleo de los términos "pintura de maque" aluda al parecido entre los marcos de las obras y las lacas namban.

25. Tovar de Teresa, op. cit., p. 98.

26. Para esta investigación se revisaron 58 documentos novohispanos que mencionan este tipo de obras. Los términos "pintura de maque" sólo aparecieron en tres documentos.

27. Véase n. I5.

28. El documento dice: "Primeramente contratan y se obligan el dicho Juan González a hacer y entregar al dicho, trece láminas de pintura y embutido de concha de a vara y cuarta en cuadro, y han de ser de la misma calidad y embutido de una de san Antonio [...] que sirva de pauta y regla para las demás que ha de hacer de la historia e imágenes que se le pidiere [...] Asimismo ha de hacer otras catorce láminas unas medianas del tamańo y forma de otra que se ha hecho para muestra de la imagen de Nuestra Señora de la Concepción [...] con la misma calidad de embutido, pero en la pintura, la historia e imágenes que le pidiere dicho factor y constarán unas y otras por memoria firmada de su nombre; y [...] entendiéndose que se han de cotejar con las muchas referidas, y estando como ellas en el embutido y flores que tienen, las ha de recibir el dicho factor por el dicho precio, y si no fueren de esa calidad, no ha de ser obligado a recibirlas". Tovar de Teresa, op. cit., p. Ior.

29. Véase María Helena Mendes Pinto, Lacas namban em Portugal, Lisboa, Inapa, I990; Oliver Impey y Christiaan Jörg, Japanese Export Lacquer 1580-I850, Ámsterdam, Hotei Publishing, 2005, y Yayoi Kawamura, "La laca japonesa de exportación en España. Del estilo namban al pictórico", Archivo Español de Arte, t. 82, núm. 325, 2009, pp. 87-93. 
Por otro lado, a finales de la década de I690, Juan y Miguel González se hallaban cada uno a la cabeza de su propio taller. El contrato de Juan González de 1699 no menciona a Miguel González. Al parecer, este último firmó sus propias obras desde $1692,{ }^{30}$ lo cual sugiere que para entonces su trabajo no se hallaba subordinado ni a su padre Tomás ni a su pariente Juan. Es posible que en sus inicios Miguel González haya trabajado con su padre, cuya muerte debió haberse producido entre i689 y i692, lo cual permitió a Miguel quedar al frente de su taller. La mención de Miguel en el "Donativo" de 1704 entre los "oficiales con tienda" sugiere que no alcanzó el grado de maestro, a diferencia de Tomás y de Juan, lo que no le impidió firmar obras ni tener tienda.

Como se mencionó, Nicolás Correa hizo tanto pinturas incrustadas de concha (fig. 16) como otras que omitieron dicho material. Sus obras son de interés no sólo por su calidad, sino también porque corresponden al apogeo del trabajo de los González. Uno de los testigos del documento de I699 de Juan González fue Francisco Correa..$^{3 \mathrm{I}}$ El pintor Juan Correa tuvo un hijo llamado Francisco, activo en esa época. ${ }^{32}$ No hay manera de saber si se trata de su hijo. Sin embargo, los pintores novohispanos a menudo tuvieron estrecha relación entre sí. Si bien los González se dedicaron a una producción particular, su trabajo fue pictórico. El "Donativo" de 1704 menciona tanto a Juan y Nicolás Correa como a Miguel González, ${ }^{33}$ y por ello no sería extraño que se hubieran conocido.

Más aún que Nicolás Correa y los González hayan hecho pinturas incrustadas de concha al mismo tiempo sugiere la existencia de cierta relación entre ambas familias. En cualquier caso, el posible vínculo con otros artistas debe tenerse en cuenta al indagar el modo como se produjo el aprendizaje pictórico de los González, tema desconocido por completo. Carezco de elementos para fijar una postura definitiva al respecto, pero me gustaría plantear la posibilidad de que los González hayan tenido cierta relación con los Correa y su dominio de la técnica pictórica haya derivado en parte de dicho vínculo.

Ya se señaló que la actividad pictórica de Juan González comenzó hacia I66o, cuando probablemente también haya empezado la de su pariente To-

30. Véase el "Apéndice".

3I. Tovar de Teresa, op. cit., p. I03.

32. Cfr. Elisa Vargaslugo et al., Juan Correa. Su vida y su obra, t. III, Cuerpo de documentos, México, Universidad Nacional Autónoma de México-Instituto de Investigaciones Estéticas, I991, pp. 43, 74, I77-I79, I98 y 35 I.

33. Mues, op. cit., p. 395. 
más. Juan Correa nació en I 646 y en 1666 ya había iniciado su actividad. ${ }^{34}$ Así pues, Tomás y Juan González difícilmente habrían sido aprendices u oficiales en su taller. Con todo, ambos pudieron haber conocido a Correa, lo que quizá les ayudó a consolidar su aprendizaje pictórico. Se ignora cuán profundos eran los conocimientos pictóricos de los González cuando empezaron a experimentar con las incrustaciones de concha. Tal vez hayan aprendido los rudimentos en algún taller poco renombrado y posteriormente, con el paulatino éxito de su producción, se hayan acercado a algún taller más próspero, como el de Juan Correa, donde podrían haber alcanzado mayor familiaridad con la técnica pictórica.

La hipótesis de la relación temprana entre ambas familias resulta sugerente por la actividad simultánea de Juan y Miguel González y Nicolás Correa, pero es importante subrayar que de momento no hay pruebas al respecto. De cualquier modo, no hay duda de que desde las primeras etapas de su producción los González se relacionaron con otros pintores. Se ignora cómo se produjo la incursión de otros artistas en estas pinturas, pero es probable que al consolidarse el gusto por el trabajo de los González, otros pintores hayan empezado a hacer obras por su cuenta, imprimiéndoles características propias.

\section{El origen de los González: ¿la influencia asiática?}

Buena parte de la historiografía se ha interesado en la relación entre las pinturas incrustadas de concha y distintas obras chinas y japonesas. ${ }^{35}$ En ocasiones

34. Elisa Vargaslugo, Novedades sobre Juan Correa, conferencia magistral, Universidad Nacional Autónoma de México-Instituto de Investigaciones Estéticas, 29 de septiembre de 20 I I.

35. Véase por ejemplo, Miguel Solá, Historia del arte hispanoamericano, Barcelona, Labor/Biblioteca de Iniciación Cultural (Sección IV, Artes Plásticas), 1935, así como Manuel Toussaint, "La pintura con incrustaciones de concha nácar en Nueva España", Anales del Instituto de Investigaciones Estéticas, vol. V, núm. 20, I952, pp. 5-20; Los enconchados: conservación y restauración de pinturas con incrustaciones de concha, México, Gobierno del Estado de Guerrero, 1986; María Paz Aguiló Alonso, "El interés por lo exótico. Precisiones acerca del coleccionismo de arte namban en el siglo Xvi”, en IX Jornadas de Arte. El arte en las cortes de Carlos Vy Felipe II, Madrid, Consejo Superior de Investigaciones Científicas, 1999, pp. I5 I-I68; Clara Bargellini, "28. Saint Francis Xavier Embarking for Asia”, en Painting a New World. Mexican Art and Life 152I-I821, Denver Art Museum, 2004, pp. I87-I89; Gustavo Curiel, "Perception of the Other and the Language of 'Chinese Mimicry' in the Decorative Arts 
se ha supuesto que existe una influencia de las pinturas de dichos orígenes. ${ }^{36}$ Sin embargo, hasta ahora sólo se ha probado la relación con las lacas japonesas namban que, como ya se señaló, se advierte en numerosos marcos y es formal, no técnica. El hecho de que se trate de una apropiación selectiva apreciable sólo en cierta parte de las obras sugiere que la problemática de las pinturas incrustadas de concha no se explica a partir de la influencia asiática. ${ }^{37}$

Sin embargo, desde 1990 se ha sugerido que los González fueron una familia de inmigrantes asiáticos, ya sea chinos o japoneses. ${ }^{38}$ En la Nueva España del primer tercio del siglo XVII hubo inmigrantes japoneses, quienes quizá hayan comenzado las experimentaciones que dieron lugar a estas pinturas. ${ }^{39}$ Téngase en cuenta que numerosos inmigrantes asiáticos se casaron con individuos de distintos orígenes nacidos en la Nueva España y algunos alcanzaron una posición social media e incluso alta. ${ }^{40} \mathrm{Al}$ parecer, esto fue más frecuente entre los japoneses. ${ }^{4}$

Debido a que la génesis de las pinturas incrustadas de concha no está ligada a ninguna de las familias conocidas del gremio de pintores, sino a unos

of New Spain", en Donna Pierce y Ronald Otsuka (eds.), Asia and Spanish America: TransPacific Artistic and Cultural Exchange 1500-1800, Denver Art Museum, 2009, pp. 19-36. 36. Véase Julieta Ávila, El influjo de la pintura china en los enconchados de Nueva España, México, Instituto Nacional de Antropología e Historia (Obra Diversa), 1997, pp. I8-38 y 66-69.

37. Sin embargo, algunas pinturas incrustadas de concha podrían tener un parecido intencional con ciertos paisajes asiáticos, como ha sugerido Ávila, ibidem, pp. 26 y 32 . Al respecto, téngase en cuenta el caso de los biombos novohispanos, que en ocasiones se informan en el arte chino, o bien en el japonés, si bien numerosos ejemplares dejan de lado el parecido con las obras asiáticas. Es decir, las similitudes con los objetos chinos y japoneses, cuando se presenta, es producto de una apropiación selectiva y deliberada.

38. Virginia Armella y Julieta Ávila han creído que los González tuvieron un origen chino, mientras Rodrigo Rivero Lake lo sugiere japonés. Véase Armella, "La influencia...", op. cit., pp. 53-I00; Ávila, op. cit.; Rivero Lake, op. cit.

39. Deborah Oropeza Keresey, “Los 'indios chinos' en la Nueva España: la inmigración de la nao de China, I565-1700”, tesis de doctorado en historia, México, El Colegio de MéxicoCentro de Estudios Históricos, 2007, inédita.

40. Ibidem, p. I93.

4I. Véase Thomas Calvo "Japoneses en Guadalajara: 'blancos de honor' durante el seiscientos mexicano”, Revista de Indias, vol. XLIII, I983, núm. I72, pp. 533-547, así como Melba Falck y Héctor Palacios, El japonés que conquistó Guadalajara: la historia de Juan de Páez en la Guadalajara del siglo XVII, Universidad de Guadalajara (México), 20Io, y "Japanese Merchants in I7th Century Guadalajara”, Revista Iberoamericana, núm. 22.2, 20I I, pp. I9I-237. 
González de los cuales apenas existe información, la hipótesis sobre su origen japonés resulta muy sugerente. Sin embargo, la relación entre dichas pinturas y las lacas japonesas se produjo en el campo de las apropiaciones y no dependió del origen de sus autores. ${ }^{42}$ Es decir, los González podrían no haber tenido ascendencia japonesa. Bien pudo haberse tratado de una familia novohispana que, sin tener origen japonés, hubiera aprovechado el gusto local por las lacas namban para experimentar con el material orgánico y los diseños de dichas obras, pero usando técnicas, materiales, soportes y contenidos iconográficos de origen europeo. En cualquier caso, la información sobre el bagaje étnico de los González no es crucial para entender la problemática de las pinturas incrustadas de concha. Por esa razón, este texto prestará mucha atención al contexto pictórico novohispano y no hará más referencias al origen de los González, que quizá nunca conoceremos con precisión.

\section{Juan González}

Desde 1937 se sabe que Juan González hizo pinturas incrustadas de concha. ${ }^{43}$ En los últimos años se ha advertido en sus obras más destacadas un dibujo virtuoso que reproduce con precisión los detalles de los modelos en los cuales se informan (figs. 4 y 5) y suelen esmerarse en el paisaje y en la ornamentación. En ocasiones el artista se interesa por enriquecer la paleta, así como por la belleza y la individualización de los rostros. Su trabajo aún no ha sido objeto de estudios particulares. ${ }^{44}$ En contraste, numerosos textos se han concentrado en Miguel González, probablemente porque firmó dos series de la Conquista de México (fig. Io), ${ }^{45}$ que desde principios del siglo xx han sido las obras más co-

42. Tanto en Europa como en los virreinatos americanos hay numerosos ejemplos de apropiaciones del arte asiático que fueron ajenas al origen de sus autores. Véanse algunas reflexiones al respecto en Curiel, "Perception of the Other...", op. cit.

43. En 1937, Genaro Estrada advirtió que el Museo Arqueológico de Madrid conservaba una Virgen de Balvanera de Juan González. Cfr. Genaro Estrada, El arte mexicano en España, México, Porrúa, 1937, pp. 23-25. La obra se encuentra actualmente en el Museo de América de Madrid.

44. Las referencias más importantes se hallan en García Sáiz, "Precisiones al estudio...", op. cit.; "Nuevos materiales...", op. cit., y Bargellini, op. cit., pp. I87-I89.

45. Véase el "Apéndice". 
nocidas hechas con esta técnica. Así pues, no sorprende que muchos ejemplares anónimos se hayan atribuido a Miguel González.

Entre las razones para analizar la producción de Juan González, conviene destacar el problema de la cronología. Recuérdese que la Smithsonian Institution conserva una Natividad firmada por dicho pintor en I662 (fig. I). En 2004 se dio a conocer un San Francisco Xavier embarcándose hacia Asia, de colección particular, firmado por el mismo artista en 1703 (fig. 3). ${ }^{46} \mathrm{El}$ nombre de Juan González no aparece en el "Donativo del gremio de pintores y doradores para la Guerra de Sucesión" de 1704, pero sí el de Miguel González, ${ }^{47}$ lo cual permite suponer que la muerte del primero se produjo a fines de 1703 o principios de 1704, cuando ya había desarrollado su actividad por más de 40 años.

La obra de 1662 sorprende por su fecha tan temprana. Sin embargo, la he examinado de manera directa y me inclino a pensar que tanto la firma como la fecha son originales. Si bien resulta extraño que las otras pinturas firmadas y fechadas de Juan González daten de 1697-I703, en mi opinión todas corresponden al mismo artista, de quien por alguna razón se conservan firmadas y fechadas una de las pinturas más tempranas y varias de las más tardías. He comparado la firma de la tabla de 1662 con las firmas de numerosos ejemplares más tardíos de Juan González, así como con la del contrato de I699 que involucra a dicho artista y la caligrafía coincide en todos los casos. ${ }^{48}$ No hay lugar para suponer que en la Natividad la firma se sobrepuso o falsificó. La obra es pequeña y ni su uso de la concha ni su solución pictórica son especialmente logrados. La pieza nunca se ha exhibido y llegó a la Smithsonian Institution en 1929 como parte de un enorme lote, obsequio del coleccionista neoyorquino John Gellatly, compuesto en su mayor parte por pinturas estadounidenses de finales del siglo XIX.49

46. Bargellini, op. cit.

47. Mues, op. cit., p. 395.

48. Dicha comparación comprende —además de la Natividad de 1662 y el San Francisco Xavier embarcándose hacia Asia de 1703 - la última tabla de la serie de la Conquista de México firmada en coautoría con Miguel González en 1698 y una Virgen de Balvanera, ambas del Museo de América. El Museo Soumaya de la ciudad de México conserva un Juicio de Guillermo III, firmado por Juan González. Sin embargo, en este caso la firma es distinta a las anteriores, por lo cual cabría la posibilidad de que no fuera original.

49. Agradezco a Jim Concha, administrador de la colección del Smithsonian American Art Museum, así como a Betsy Anderson, de la oficina curatorial de la Smithsonian Institution, todos sus comentarios sobre este tema. 
3. Juan González, San Francisco Xavier embarcándose hacia Asia, I703, ¿óleo y temple? e incrustaciones de concha nácar sobre tabla, II $3 \times 91.4 \mathrm{~cm}$. Colección particular. Imagen tomada de Joseph J. Rishel

y Suzanne Stratton-Pruitt (comps.), Revelaciones. Las artes en América Latina, 1492-1820,

México, Fondo de Cultura Económica/Antiguo Colegio de San Ildefonso/ Philadelphia Museum of Art/Los Angeles County Museum of Art, 2007, p. I24.

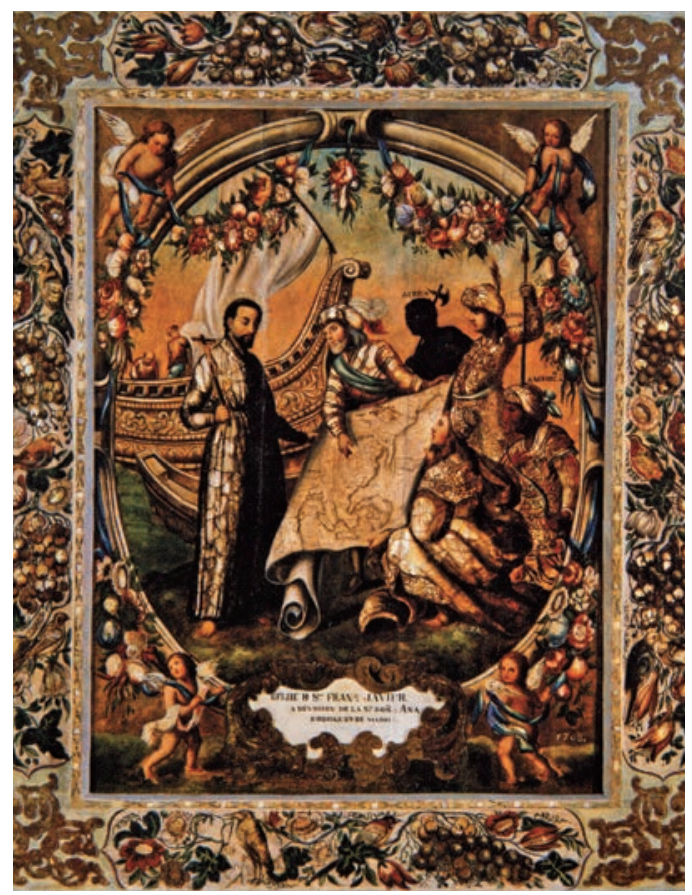

En conjunto, las obras de Juan González destacan por sus diferencias de factura, especialmente evidentes al comparar la Natividad y el San Francisco Xavier embarcándose hacia Asia de 1703 (fig. 3). El dibujo muestra más soltura en esta última tabla. Por ejemplo, los rostros exhiben cierto esmero en ambos casos, pero los de la obra de 1703 son más logrados. Más aún, en la Natividad el rostro del niño es poco detallado, pese a su importancia. Asimismo, en el San Francisco Xavier embarcándose hacia Asia las transparencias de la capa pictórica aumentan la luminosidad del material, mientras que en la Natividad el artista no logró armonizar el brillo de la concha y la capa pictórica. Esta obra posee pocos fragmentos de dicho material, embutidos en trozos irregulares únicamente sobre una parte de las vestiduras de los personajes, mientras que la representación jesuita exhibe numerosos fragmentos de concha tanto en las vestiduras de los personajes como en el fondo y el marco.

Desde luego, tiene interés indagar las razones de estos contrastes de factura. Acaso Juan González aún no había alcanzado el virtuosismo en la época 
en que hizo la Natividad. También es posible que buena parte de la obra haya sido realizada por otros miembros del taller, quizá porque el presupuesto fuera bajo. Por otro lado, el uso de la pintura sobre la concha representó retos técnicos complejos, que al parecer ni siquiera los especialistas resolvieron exitosamente en todos los casos.

Aunque no se ha localizado la fuente precisa donde pudo haberse informado la Natividad, se advierte su parecido con una Adoración de los pastores del círculo de Federico Zuccaro (segunda mitad del siglo xvi), $5^{\circ}$ que exhibe en primer plano un gato y un perro y a la derecha un par de ángeles músicos, ausentes de la tabla de González. Ahora bien, ambas muestran en la parte superior a la izquierda del espectador, como escena secundaria, la aparición del ángel a los pastores. Asimismo, las dos exhiben una canasta en primer plano y un buey detrás de los personajes, a la izquierda del espectador. En la obra de González, tanto José como los pastores son jóvenes, no así en el dibujo europeo. Esto sugiere que González estudió otras pinturas novohispanas, donde se suele representar a José como un hombre joven. El tema gozó de gran popularidad en la época y es posible que el artista haya hecho numerosas versiones del mismo, tomando elementos de distintos modelos.

$\mathrm{Al}$ respecto, cabe mencionar el parecido de esta Natividad con la que aparece como escena secundaria en la tabla Santiago el Mayor de una serie de I2 tablas de las Alegorías del Credo de Miguel González (fig. 2). ${ }^{5 \mathrm{I}}$ Ambas exhiben pocas diferencias de factura entre sí. La primera es apaisada y la última tiene formato vertical, pero tanto las figuras como el fondo son similares en las dos escenas, las cuales muestran a María a la izquierda y a José a la derecha del espectador. Miguel González incluye en medio de ellos a un pastor muy joven, parecido al personaje que Juan González ubica en la extrema izquierda. La tabla de Miguel González exhibe a la izquierda del espectador a una mujer con un cántaro sobre la cabeza y a la derecha un buey, a la inversa de lo que ocurre en la tabla de Juan González. El personaje femenino es muy parecido en ambas tablas y deriva de un modelo de Rubens de 1617.52 La composición de Rubens es más sencilla que la del círculo de Zuccaro, pues omite la escena secundaria con los pastores, así como a los ángeles músicos y el gato, también

50. La imagen está disponible en www.museodelprado.es/coleccion/galeria-on-line.

5I. La serie se comentará más adelante. Véanse pp. I45-I50.

52. Rubens hizo numerosas variaciones de este tema. La que aquí se menciona mide $68 \times$ $200 \mathrm{~cm}$ y se encuentra en el Museo de Bellas Artes de Marsella. 
ausentes de la tabla de Miguel González. Es decir, esta última es más cercana al modelo de Rubens que al dibujo del círculo de Zuccaro.

Miguel González sitúa en primer plano el fuste de una columna caída, ausente tanto de la obra de I662 como de los modelos europeos comentados, pero frecuente en las pinturas de los González, así como en los grabados manieristas en los que a menudo se informaron. Esto sugiere que el artista tomó elementos de distintos modelos para su composición. Esta idea se refuerza por el parecido entre las versiones de Juan y Miguel González. La obra de este último podría haberse informado en parte en la de Juan, que sin duda fue anterior. Las similitudes entre ambas permiten suponer que algunos trabajos anónimos parecidos entre sí podrían haber sido realizados por los González de manera separada. De ahí la necesidad de proceder con cautela al atribuirles obras.

Por otra parte, el San Francisco Xavier embarcándose hacia Asia (fig. 3) de Juan González se basa en un modelo de Cornelis Bloemaert al que guarda notable fidelidad, ${ }^{53}$ incluyendo los detalles del mapa de Asia, ${ }^{54}$ donde uno de sus acompañantes indica a Francisco Xavier la ubicación de China. Se trata de la única pintura incrustada de concha conocida que incluye un mapa, por lo que la habilidad de la ejecución es digna de interés. Dado que la cartografía se hallaba desarrollada en la Nueva España en la época de los González, 55 el artista podría haber contratado un cartógrafo. Sin embargo, a duras penas el presupuesto de la obra se lo habría permitido. Así pues, posiblemente Juan González hizo suyo el interés por la cartografía, planteándose el reto excepcional de copiar un mapa con el que no estaba familiarizado. Los trazos que reproducen con precisión dicho mapa sugieren que Juan González se convirtió en uno de los artistas preferidos para este tipo de trabajos gracias a sus habilidades como dibujante.

El pintor se esmeró en la representación de los rostros, informados en Bloemaert. La obra también incluye una rica ornamentación y numerosos de-

53. El modelo fue identificado por Bargellini, op. cit., p. I87. Por otro lado, García Sáiz ha advertido que Juan González "se muestra muy apegado a las ilustraciones que le sirven de modelo, tal y como demuestra en otros ejemplos, como las series dedicadas a la vida de san Ignacio y a la toma de Viena por los turcos". García Sáiz, "Nuevos materiales...", op. cit., p. I38.

54. Agradezco a Elena Isabel Estrada de Gerlero el haber llamado mi atención sobre este tema.

55. Para una introducción general al tema, véase el documento anónimo del Instituto Nacional de Estadística y Geografía "La cartografía y el territorio nacional: una breve retrospectiva”, disponible en http://www.inegi.gob.mx/prod_serv/contenidos/espanol/bvinegi/ productos/integracion/especiales/infogeo/georw.pdf; consultado el i9 de septiembre de 20 I I. 
talles ajenos al modelo, los cuales prueban que González lo usó como mero punto de partida para crear una obra distinta. Por ejemplo, tanto las vestiduras de los personajes como el barco que se halla en segundo plano, listo para la partida de Francisco Xavier, poseen ricos efectos lumínicos ajenos a la obra de Bloemaert. González varió el formato cuadrado del grabado a uno en forma de medallón -inscrito en la tabla rectangular que sirve de soporte-, donde presenta sendos pares de ángeles niños tenantes, uno en la parte superior y otro en la inferior. El pintor omitió a dos personajes presentes en el grabado: el primero está en el mástil del barco desplegando la vela, en el área que en la obra novohispana está cubierta por una guirnalda, y el otro aparece en segundo plano, en el extremo derecho, junto a las personificaciones de los continentes. Estas variaciones demuestran que González hizo ajustes para enriquecer la obra con la ornamentación característica de su trabajo.

La guirnalda exhibe flores y hojas bien logradas, lo mismo que el marco, el cual incluye además aves y racimos de uvas que poseen cierta gradación tonal y se recortan sobre un fondo café claro, produciendo un efecto contrastante a los fondos negros de la mayoría de los marcos de este tipo (figs. 7, I I-I4 y I8). ${ }^{56}$ Las hojas al parecer de parra exhiben un tono oscuro de verde y nervaduras verde claro. Las figuras revelan mucha atención a los detalles, así como un exacerbado interés por la representación de la naturaleza. El esmero puesto en la escena, así como en la guirnalda y el marco, sugiere que González se involucró directamente en las tres partes de la obra. El virtuosismo de esta tabla corresponde a un trabajo de madurez que sintetiza los conocimientos y habilidades adquiridos por Juan González después de más de 40 años de trabajo. El San Francisco Xavier embarcándose hacia Asia no sólo es la obra firmada más notable de este artista, sino una de las más logradas de cuantas subsisten. Es decir, entre los ejemplares anónimos destacados que se conservan, debe haber obras de Juan González.

Otro ejemplo de virtuoso apego de este pintor a su modelo se halla en una Alegoría del primer mandamiento (fig. 4) ${ }^{57}$ de colección particular, cuya composición deriva de una obra de Martín de Vos grabada por Adriaen Collaert, dedicada a los diez mandamientos y parte de una serie sobre el Éxodo (fig. 5$) .5^{8}$

56. Los siguientes comentarios aparecieron previamente en mi texto "Mother-of-pearl Inlaid Frames. The Use of Japanese Ornamentation in the Paintings of New Spain", en Pierce y Otsuka (eds.), op. cit., pp. I40-I42.

57. La obra se dio a conocer en García Sáiz, "Nuevos materiales...”, op. cit., pp. I37-I39.

58. Véase Christiaan Schuckman (comp.) y Hoop Scheffer (ed.), Hollstein’s Dutch \& Flemish 


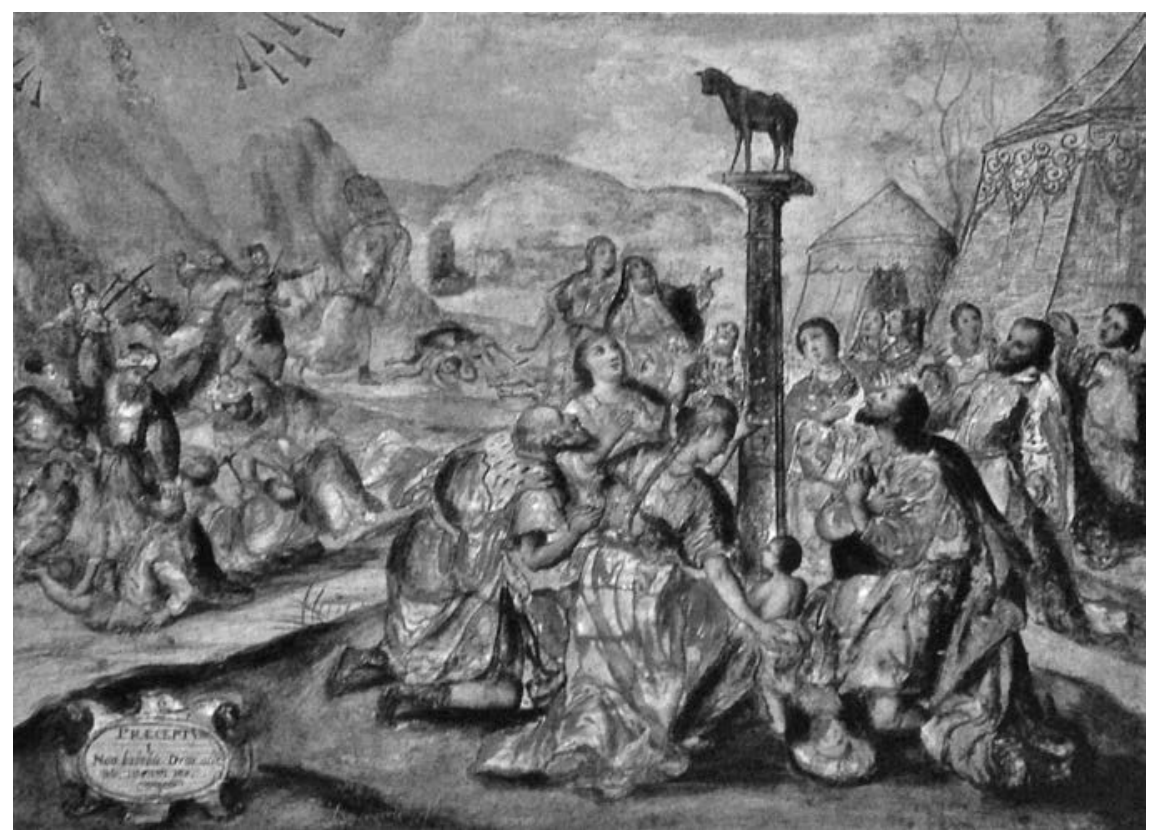

4. Juan González, Alegoria del primer mandamiento, de la serie Los diez mandamientos, finales del siglo XVII, ¿̨óleo y temple? e incrustaciones de concha nácar sobre tabla, $43.8 \times 58 \mathrm{~cm}$. Colección particular. Imagen tomada de García Sáiz, "Nuevos materiales...", op. cit. (vid. supra n. 17), p. I39.

La composición muestra en primer plano a los israelitas adorando al becerro de oro y González reprodujo con soltura numerosos detalles. Todos los rostros están individualizados y el artista resolvió virtuosamente la expresividad de las figuras, que exacerban el dramatismo de la escena. Más aún, la obra exhibe una belleza particular debido a la luminosidad que le dan los trozos de concha, relativamente grandes y regulares, lo cual revela una factura muy cuidadosa.

La prolongada actividad de Juan González complica la identificación de las características de sus obras. Si bien tanto el San Francisco Xavier embarcándose hacia Asia como la Alegoría del primer mandamiento muestran una notable evolución estilística respecto a la Natividad, dicha evolución no posee una explica-

Etchings, Engravings and Woodcuts: 1450-1700, vol. XLV: Marten de Vos plates: part I, Rótterdam/Ámsterdam, Sound \& Vision Interactive/Rijksprentenkabinet, I995, p. 35. 


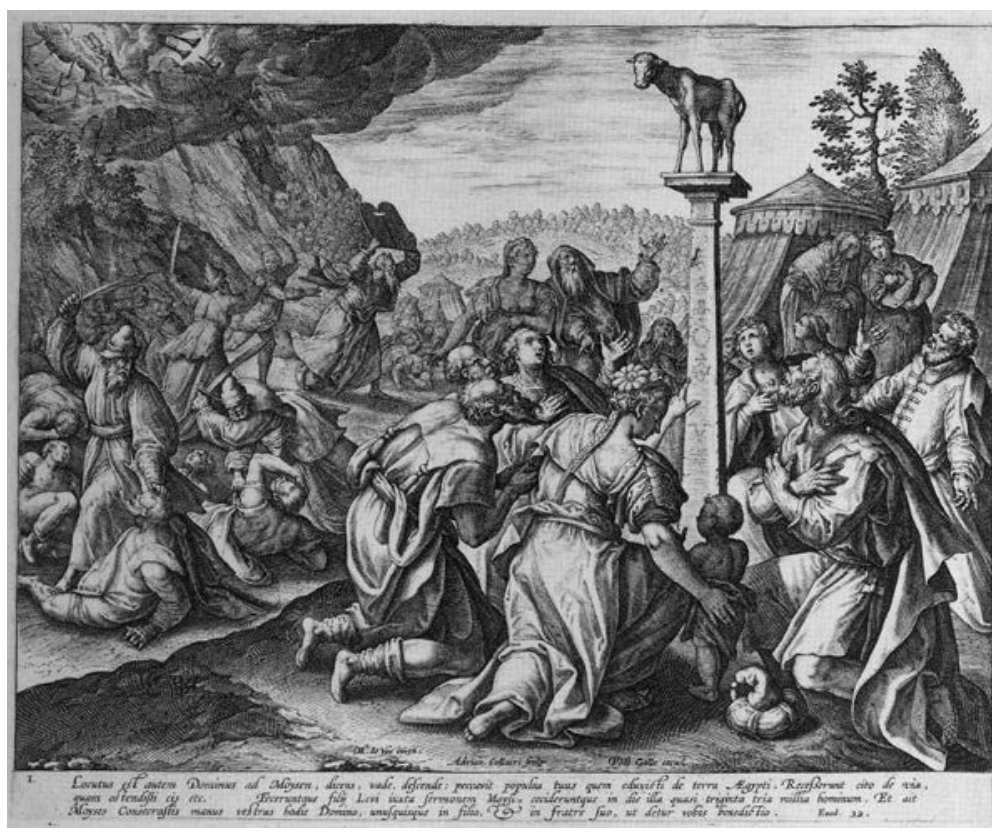

5. Adriaen Collaert a partir de Martín de Vos, No adorarás a otro Dios que a mí, de la serie Los diez mandamientos, después de I586. Imagen tomada de Schuckman (comp.) y Scheffer (ed.), op. cit. (vid. supra n. 58), p. 35.

ción simple, pues incluso sus últimos trabajos muestran una calidad contrastante. 59 Esto hace difícil precisar su posible autoría en los ejemplares anónimos y demuestra que para avanzar en el conocimiento del tema es imprescindible nutrir los análisis estilísticos con estudios técnicos. Aunque existen numerosas interrogantes respecto a este artista, queda claro que su actividad fue muy importante en relación con las pinturas incrustadas de concha y la desarrolló

59. La autora ha advertido el extremo apego de una serie de la Vida de san Ignacio de Loyola de Juan González, de I697, a los grabados que le sirvieron de modelo, limitándose a incorporar ciertos elementos decorativos. García Sáiz añade: "Un año más tarde, cuando Juan González firma la última tabla de la serie madrileńa, que reproduce distintos pasajes de la Conquista de México, todas estas dificultades han desaparecido. Y hasta tal grado esto es así que es difícil establecer el nivel de contribución de este pintor en la obra en común, partiendo de lo realizado meses antes". García Sáiz, "Precisiones al estudio...”, op. cit., p. I I I. 
de manera independiente. Asimismo, su producción fue excepcionalmente larga y merece seguir analizándose.

\section{Las Alegorías del Credo de Miguel González}

Esta serie de I2 tablas se divide entre el Patrimonio Artístico del Banco Nacional de México y el Museo Nacional del Virreinato de México (figs. 6 y 8$)^{60}$ y nunca ha sido objeto de estudios particulares, a pesar de saberse de su existencia desde 1931 y de haber sido reproducida íntegramente desde $1984 .{ }^{61}$ Se trata de tablas muy ricas cuyo contraste con las series conocidas de la Conquista de México permite advertir otros aspectos del trabajo de Miguel González. ${ }^{62}$

El tema tuvo numerosas representaciones europeas en el siglo Xvi. ${ }^{63}$ Recientemente, Marta Fajardo de Rueda ha comentado una serie del pintor quiteño Miguel de Santiago, ${ }^{64}$ informada en la versión de Johan Sadeler I (I579), basada en los diseños de Martín de Vos. Aquí se comentará esa versión, así como otra grabada por Adriaen Collaert hacia 1600, ${ }^{65}$ pues las obras de Miguel González guardan estrecha relación con ambas. Esto se advierte en la tabla 2, San Andrés. Creo en Jesucristo, su único hijo que es solo Señor nuestro, que muestra la transfiguración (fig. 6). La representación es también muy semejante a la que aparece en una serie anónima — pero sin duda ligada a los González— de

6o. Agradezco a María del Refugio Cárdenas Ruelas y Karola Torres, del Patrimonio Artístico del Banco Nacional de México, así como a Verónica Zaragoza, del Museo Nacional del Virreinato, por facilitarme el acceso a las obras.

6I. Véase Manuel Romero de Terreros, "Miguel González”, Contemporáneos, núm. 35, abril de I93I, pp. 83-84, así como Marta Dujovne, Las pinturas con incrustaciones de nácar, México, Universidad Nacional Autónoma de México-Instituto de Investigaciones Estéticas, 1984, pp. 29-50.

62. Respecto al trabajo de Miguel González, véase García Sáiz, "Precisiones al estudio...", op. cit., y García Sáiz y Serrera, op. cit.

63. El tema también se conoce como el "Credo de los apóstoles", pues en la Edad Media se difundió la idea de que la oración del Credo había sido formulada de manera conjunta por los apóstoles, al ir pronunciando cada apóstol las frases que la conforman.

64. Marta Fajardo de Rueda, "Del grabado europeo a la pintura americana. La serie El Credo del pintor quiteño Miguel de Santiago", Revista de Historia Regional y Local, vol. 3, núm. 5, enero-junio de 20II, pp. I9I-2I4.

65. Al respecto, Fajardo ha señalado: "el modelo es el mismo, tan sólo difieren en algunos detalles, entre ellos el formato y las frases aclaratorias sobre cada título que no incluye Collaert”. Ibidem, p. 198. 


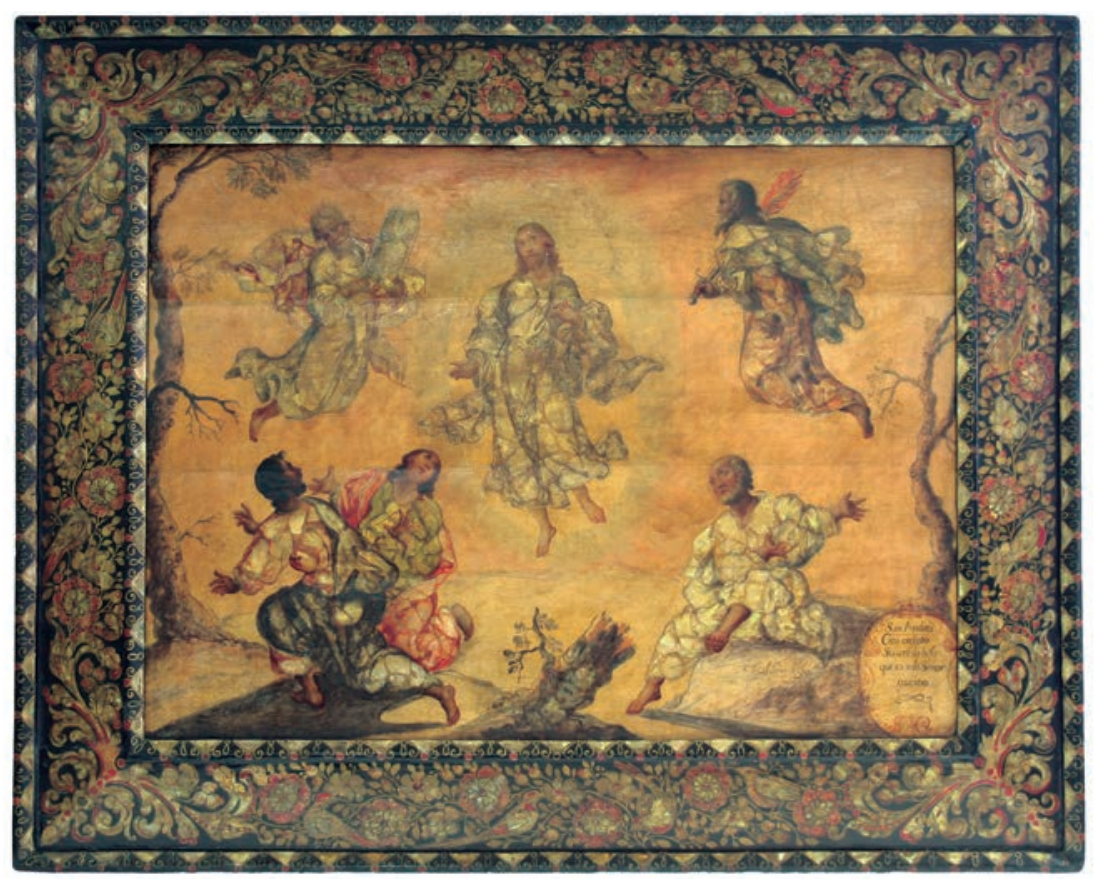

6. Miguel González, San Andrés, serie de las Alegorías del Credo, finales del siglo XviIprincipios del siglo XVIII, ¿̇óleo y temple? e incrustaciones de concha nácar sobre tabla, 6I $\times 86 \mathrm{~cm}$. Museo Nacional del Virreinato, Tepotzotlán. Conaculta-InAH-MÉx. "Reproducción autorizada por el Instituto Nacional de Antropología e Historia”.

la Vida de Cristo (fig. 7). ${ }^{66}$ Ahora bien, la versión de las Alegorías del Credo es más esmerada, pues los rostros resultan más detallados y el de Jesús está mejor logrado. Asimismo, esta tabla incluye sendos árboles en los extremos de la composición y un pequeño tronco trunco en el primer plano, habituales en las obras de los González, ${ }^{67}$ aunque ausentes de la tabla perteneciente a la Vida de Cristo, cuyo fondo es muy sencillo.

El parecido es pronunciado en la parte superior, pues tanto Jesús como Moisés y el profeta Elías están dispuestos de manera muy similar en ambas tablas. Por su parte, los apóstoles que aparecen en la parte inferior exhiben diferencias notables. En los dos casos Pedro es un hombre mayor, con barba,

66. La serie se comentará más adelante. Véase pp. I57-I64.

67. García Sáiz y Serrera, op. cit., p. 80. 


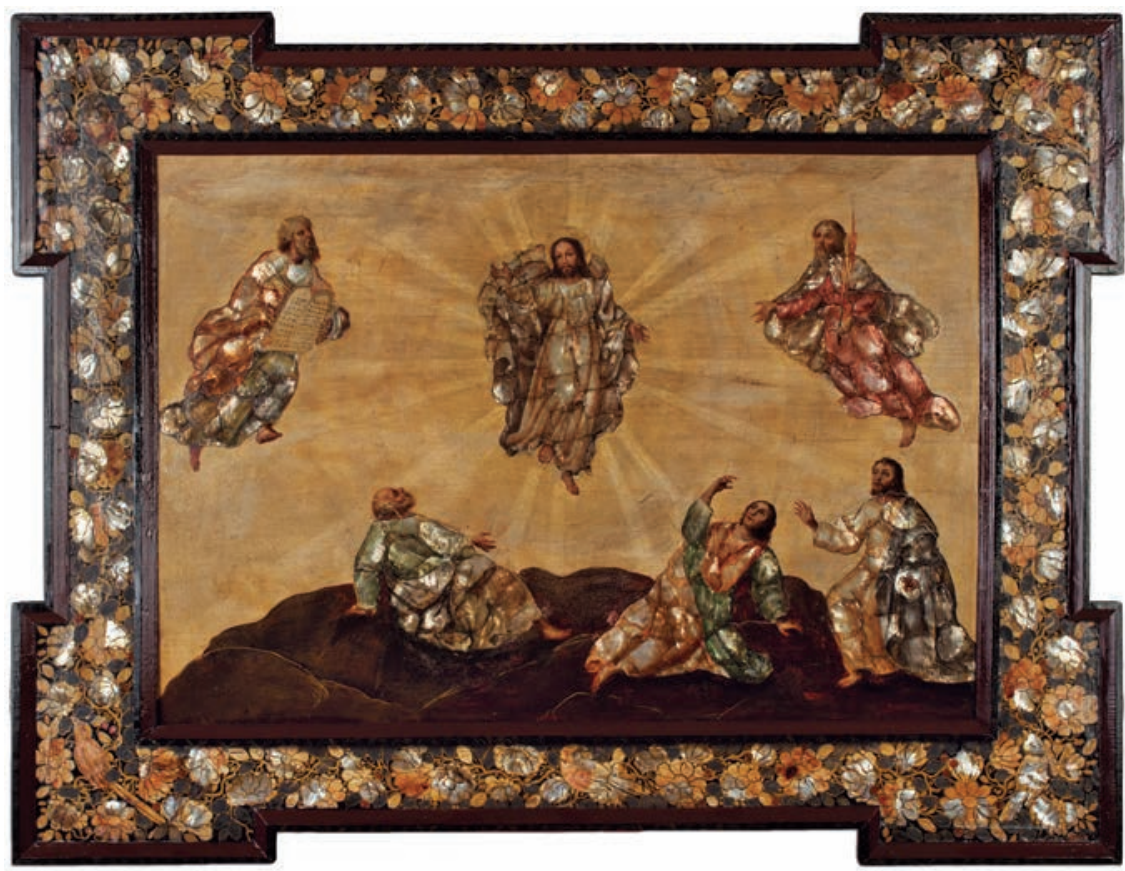

7. Anónimo, La Transfiguración, de la serie Vida de Cristo, finales del siglo xviI-principios del siglo XviII, ¿̨óleo y temple? e incrustaciones de concha nácar sobre tabla, $69 \times 102 \mathrm{~cm}$. Museo de América, Madrid, núm. de inv. oor 47.

ubicado en la tabla de la Vida de Cristo a la izquierda del espectador, mientras que Santiago y Juan se hallan a la derecha. En contraste, la tabla de las Alegorías del Credo muestra a Pedro a la derecha y a los hermanos del lado opuesto. Pese a que sus gestos y actitudes son distintos a los de la otra tabla mencionada, su tratamiento es muy similar. ${ }^{68}$ Como se verá adelante, en otros casos el uso de los mismos modelos produce soluciones distintas. Es decir, más allá del uso del mismo modelo, la factura parecida de ambas tablas sugiere que Miguel González podría haberse involucrado en la serie de la Vida de Cristo.

Por su parte, el Juicio Final representado en la tabla San Mateo (fig. 8) ex-

68. El parecido entre ambas obras resulta aún más significativo si se tiene en cuenta que, como se ha observado, el artista mostró cierta independencia respecto a sus modelos y varió las soluciones de sus obras. Véase García Sáiz, "Precisiones al estudio...”, op. cit., pp. II3-I I4, y "Nuevos materiales...", op. cit., p. I38. 


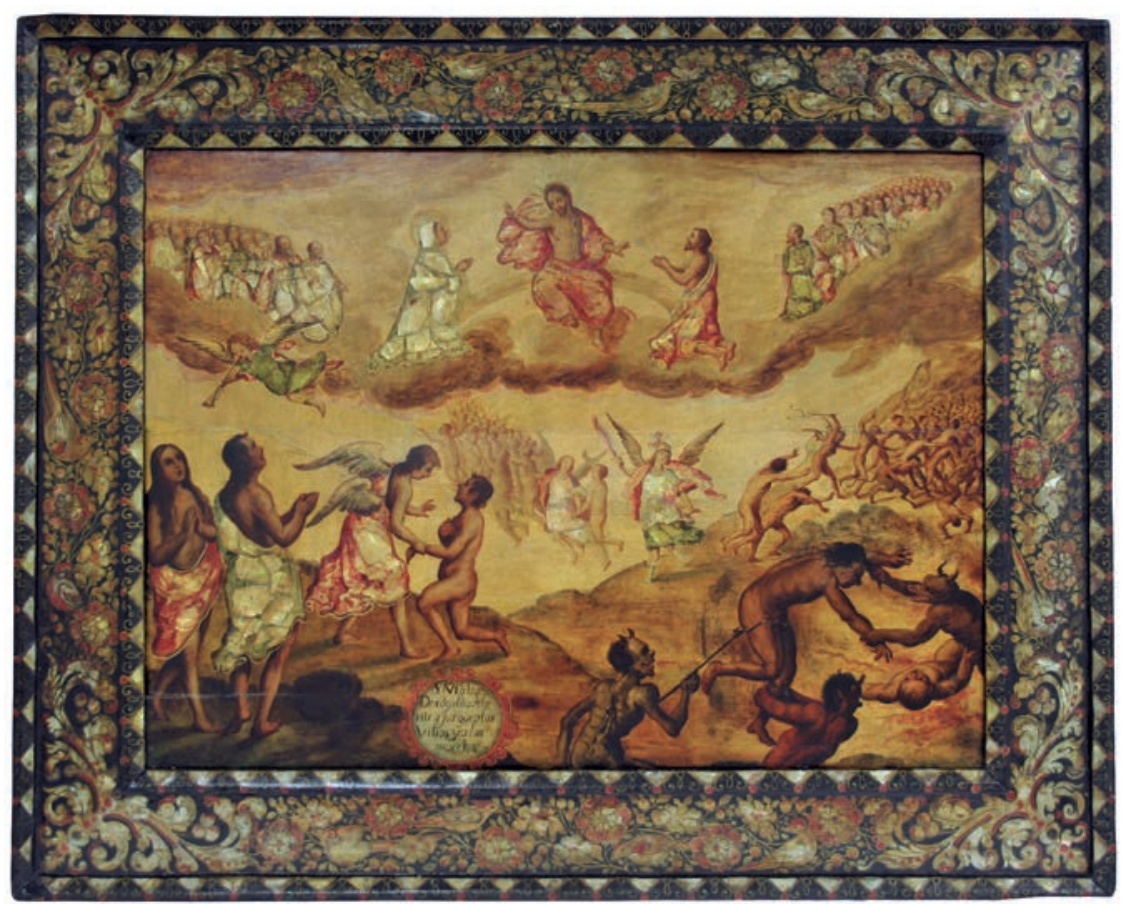

8. Miguel González, San Mateo, serie de las Alegorías del Credo, finales del siglo XviI-principios del siglo XVIII, óleo, temple e incrustaciones de concha nácar sobre tabla, 6I × $86 \mathrm{~cm}$. Museo Nacional del Virreinato, Tepotzotlán. Conaculta-INAH-MÉx. "Reproducción autorizada por el Instituto Nacional de Antropología e Historia”.

hibe gran parecido con el modelo de De Vos-Collaert (fig. 9) en la parte superior, que muestra a Jesús en Majestad y, a ambos lados, a una comitiva celestial presidida por María y san Juan en actitud orante. Ahora bien, el fondo neutro de la obra de González contrasta con los elaborados detalles del modelo flamenco. La multitud situada debajo de Jesús es muy parecida en ambas obras, pero en la novohispana los personajes no son tan numerosos y se omiten dos de los cuatro ángeles que hacen sonar sus trompetas anunciando el Apocalipsis.

El primer plano muestra grandes diferencias. Las dos obras exhiben a una pareja en el extremo izquierdo, pero De Vos-Collaert muestra a los personajes desnudos y al hombre de frente al espectador, mientras que en la obra de González ambos visten túnicas y se dirigen al Redentor en actitud piadosa. En el modelo flamenco, junto a dichos personajes se encuentra un ángel ante 


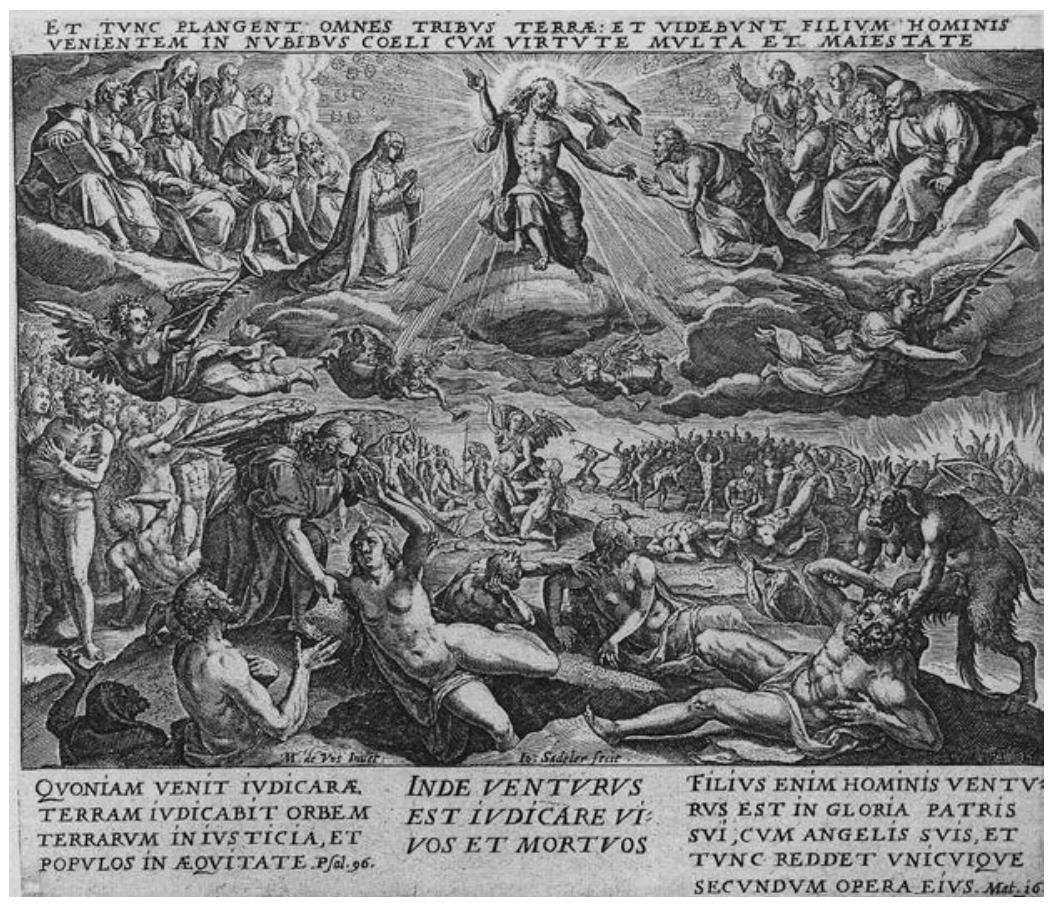

9. Adriaen Collaert a partir de Martín de Vos, El Juicio Final, serie del Credo de los apóstoles. Imagen tomada de Fajardo de Rueda, op. cit. (vid. supra n. 64), p. 205.

el que se inclinan, suplicantes, un hombre y una mujer desnudos. González omitió a la mujer, así como a otro hombre desnudo que en la obra de De VosCollaert se halla de espaldas en primer plano, a la derecha.

A diferencia de González, Santiago no evitó los desnudos y sus obras exhiben mayor parecido con los modelos flamencos. Así pues, lejos de limitarse a copiar dichos modelos, González los puso al servicio de sus propias necesidades. Esta serie se encontraba en una iglesia cercana a la Villa de Guadalupe a principios del siglo $\mathrm{xx} .{ }^{69} \mathrm{Si}$ bien se ignora si se hizo expresamente para exhibirse en un recinto público, es sabido que la Iglesia novohispana exigió tratar los temas religiosos con decoro. Estos ejemplos demuestran que Miguel González estudió sus modelos con atención e introdujo variaciones significativas, acordes con los intereses de sus comitentes.

69. Romero de Terreros, op. cit. 
El artista enriqueció la serie con recursos lumínicos y ornamentales propios de su producción. Los marcos resultan muy atrayentes, pues las entrecalles están pobladas por tantas flores, aves y hojas que apenas se distingue el color del fondo. Algunas aves muestran posturas complicadas, poco naturales. Por ejemplo, el larguero derecho del marco de la Sagrada Familia exhibe un ave escorzada en pleno vuelo, que produce la ilusión de acercarse al espectador, pues la cabeza está adelantada, mientras el cuerpo permanece en un segundo plano. Los González sabían que buena parte del atractivo de sus obras residía en los marcos, lo cual explica su esmero en sus mejores obras.

\section{El trabajo conjunto de Miguel y Juan González: la Serie I del Museo de América}

Las series de la Conquista de México han interesado a casi todos los autores que se han referido a estas pinturas y en los últimos años se han hecho importantes aportaciones a su estudio. ${ }^{70}$ Aquí comentaré brevemente la llamada Serie I del Museo de América, dejando de lado el tema representado y su iconografía, pues la razón para incluirla en esta revisión es que se trata del único trabajo donde sin duda participaron tanto Miguel como Juan González. Esta serie, firmada en I698, se hallaba entre los bienes de Carlos II en I700, lo cual sugiere que se hizo ex profeso para enviarla al monarca. ${ }^{71}$ Cada uno de los González firmó una tabla. Si bien se ignora cómo se dividieron el trabajo, toda la serie presenta un tratamiento similar, como si ambos hubiesen intervenido en todas las tablas, o bien, hubiesen homogeneizado deliberadamente su factura.

70. Véase Marta Dujovne, La Conquista de México por Miguel González, Buenos Aires, Asociación Amigos del Museo Nacional de Bellas Artes, 1972; María Concepción García Sáiz, "La conquista militar y los enconchados. Las peculiaridades de un patrocinio indiano", en Los pinceles de la historia. El origen del reino de la Nueva España, México, Consejo Nacional para la Cultura y las Artes-Instituto Nacional de Bellas Artes/Universidad Nacional Autónoma de México-Instituto de Investigaciones Estéticas, I999; Martínez del Río de Redo, op. cit.; Francisco Montes González, "Apuntes iconográficos a la serie mayor de enconchados de la Conquista de México del Museo de América de Madrid”, en XVI Congreso Nacional de Historia del Arte. La multiculturalidad en las artes y en la arquitectura, Las Palmas de Gran Canaria, Anroart, 2006, vol. 2, pp. 803-8I I, y Michael Schreffler, The Art of Allegiance: Visual Culture and Imperial Power in Baroque New Spain, University Park, Penn State University Press, 2007. 7I. García Sáiz, "La conquista militar...”, op. cit., p. I I I. 
Muchas tablas exhiben dos escenas, aunque algunas incluyen tres y otras solamente una. Siempre hay una a la cual se concede protagonismo, pero todas reciben un tratamiento similar. Las obras muestran un uso enfático de la línea e interés en el paisaje, no así en los rostros, que a menudo son abocetados y poco individualizados, a excepción de los de los personajes principales. Destaca la tabla I7, Retirada de los españoles la Noche Triste, donde el rostro de Cortés es muy detallado. Es decir, la falta de individualización de la mayoría de los rostros no se debe a una incapacidad de los artistas. Quizá otros miembros del taller se hayan encargado de buena parte de las figuras, o los González hayan trabajado con cierta premura. Al respecto, téngase en cuenta que algunos motivos parecen haber quedado inconclusos. Un ejemplo destacado se halla en la tabla 4, Entra Cortés en Zempoala y le recibe el cacique gordo (fig. Io), pues el dibujo de la tilma del cacique se distingue con facilidad bajo la concha, no así sobre el material, el cual rebasa los límites del dibujo subyacente y no muestra indicios de que se haya intentado pintar encima. Esto le da un aspecto inconcluso que desconcierta en la escena principal de una serie tan importante. Se advierte el contraste con el resto de la composición, que está muy trabajada, e igualmente con los otros trabajos firmados tanto por Miguel como por Juan González. Así pues, no es posible atribuir con certeza el descuido a ninguno de ellos.

Desde luego, la autoría conjunta de Miguel y Juan González merece reflexión. El quehacer pictórico novohispano tuvo lugar en talleres donde tanto los oficiales como los aprendices intervinieron en las obras, pero el derecho a firmarlas correspondió sólo al maestro. ${ }^{72}$ En este caso, la autoría conjunta debe haberse concebido originalmente, pues Juan González seguía vivo en 1703 y Miguel González en 1704. Así, no hay lugar para suponer que Juan González (quien firmó la última tabla) haya tomado el encargo por la muerte de Miguel González, quien firmó la tabla 9. Más aún, la unidad estilística sugiere que ambos convinieron desde el principio en sus características.

Recuérdese que ambos artistas pertenecieron a generaciones distintas. En la última década del siglo xviI, el prestigio de Juan González se hallaba establecido tras más de 30 años haciendo pinturas incrustadas de concha, mientras que Miguel González parece haber ganado fama rápidamente. Es probable que la decisión de contratar a los dos haya sido del comitente, pues cada artista diri-

72. Sin embargo, numerosos talleres fueron dirigidos por oficiales que firmaron obras. $C f r$. Mues, op. cit., pp. 394-396. 


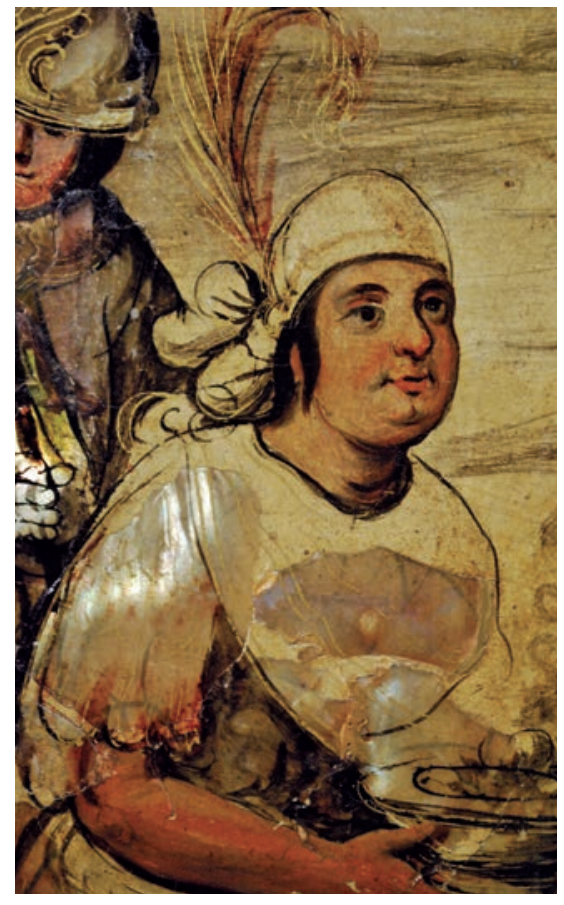

Io. Miguel y Juan González, detalle de Entra Cortés a Zempoala y le recibe el cacique gordo, de la serie Conquista de México, 1698. Museo de América, Madrid, núm. de inv. 00I04.

gió su propio taller y en 1698 el gusto por sus obras se hallaba en su apogeo. Es decir, no hay razón para suponer que tuvieron necesidad de trabajar juntos habitualmente. Asimismo, el interés de ambos en firmar la serie sugiere que estuvieron conscientes de la alta dignidad de su destinatario.

Por otro lado, si bien estas tablas exhiben cierto parecido con las de otras series de la Conquista de México que se conocen, ${ }^{73}$ su tratamiento no muestra una cercanía extrema ni con dichas obras ni con otras pinturas de Miguel o de Juan González. Así, esta serie ofrece otro ejemplo de los tropiezos de la clasificación estilística al intentar explicar la versatilidad del trabajo de los González, pues incluso si el análisis se limita al trabajo de los artistas más conocidos, su factura revela una notable diversidad que es importante seguir estudiando. En sí misma, tal diversidad demuestra que este segmento de la pintura novohispana tuvo más importancia de la que se le ha concedido hasta ahora. 


\section{Una atribución a Miguel González}

La obra que se comentará aquí demuestra que, pese a la heterogeneidad del trabajo de los González, es posible precisar la autoría de ciertos trabajos anónimos. Dicha obra, Alegoría de la Encarnación, de la Hermandad y Archicofradía de los Nazarenos del Dulce Nombre de Jesús de Sevilla (fig. II), es descrita por Rafael Ramos Sosa como

una exposición sobre la promesa del envío del Mesías, su cumplimiento y la genealogía de Cristo; subrayando la armonía entre el Antiguo y el Nuevo Testamento. En la escena central de la Anunciación confluyen la composición, organizada por una arquitectura de fuerte perspectiva cónica, y la atención de todos los espectadores que contemplan el misterio. Arriba aparece un rompimiento de gloria con Dios Padre y el Espíritu Santo con coros angélicos. El plano de tierra evoca la nave de un templo columnado donde asisten doce personajes al acontecimiento que señala la plenitud de los tiempos. Estos representan a cuatro reyes con sus coronas: David (arpa), Salomón y otros dos; patriarcas y profetas: posiblemente Moisés, Abraham, Isaías, Jeremías y Zacarías o Ageo (con turbantes); y tres apóstoles: tal vez Mateo, Marcos y Juan (sin tocado en la cabeza) que son los que recogen más directamente las profecías de Zacarías. A la alegría del hecho le acompañan los ángeles músicos, también en las tribunas con órganos, y al fondo la amplitud del paisaje con tintes naturalistas. ${ }^{74}$

La composición se relaciona con un grabado de Hendrick Goltzius de 1580 aproximadamente, ${ }^{75}$ que a la vez resulta similar a uno de Cornelis Cort, de I57I. ${ }^{76}$ El parecido es más estrecho con la obra de Cort, pues ambas son apaisadas y muestran a David tocando el arpa inmediatamente a la izquierda de María, que aparece frente al arcángel Gabriel. El grabado tiene forma de arco de medio punto, lo cual no ocurre en la pintura novohispana. Por su parte, la obra de Goltzius es vertical y María aparece volviéndose hacia el ángel, formando una serpentinata. Los gestos de los profetas son ajenos a la pintura no-

74. Rafael Ramos Sosa, Alegoría de la Encarnación, en Signos de evangelización: Sevilla y las hermandades en Hispanoamérica, Sevilla, Fundación El Monte, I999, p. 214. Agradezco a Rafael Ramos Sosa el gentil envío de este texto.

75. Véase García Sáiz y Serrera, op. cit., p. 70, así como Ramos Sosa, op. cit., p. 2 I 4.

76. Dicha obra se basó en un fresco de Federico Zuccaro de la desaparecida iglesia de Santa Maria Annunziata de Roma. Cfr. Michael Bury, The Print in Italy 1550-1620, Londres, British Museum, 200I, núm. 74 (catálogo de exhibición). 
vohispana, en la que los fragmentos de concha son irregulares y no cubren por completo las vestiduras de los personajes. La técnica pictórica es virtuosa, pues el nácar mantiene su luminosidad, ayudada por la suavidad de los colores.

Tanto la obra de Goltzius como la de Cort muestran los símbolos marianos apretadamente dispuestos en el jardín. ${ }^{77}$ En la obra novohispana dichas figuras aparecen en los 20 medallones que adornan el marco, cuyo esmerado trabajo a la vez embellece la obra y retroalimenta el tema representado, permitiéndole ejercer mayor efecto sobre el espectador. ${ }^{78}$ La identificación de los motivos es sencilla en algunos casos, mientras que en otros resulta compleja. En la parte superior es fácil identificar las azucenas, ${ }^{79}$ la luna, el sol, los lirios y la escalera. En el lado inferior aparecen la fuente, el pozo de aguas vivas y la Ciudad de Dios. Por su parte, el larguero izquierdo muestra en la parte superior el espejo sin mancha. El larguero derecho posee en la parte superior un motivo arquitectónico que quizá represente la Casa de Oro. Debajo aparecen la palma, la Puerta del Cielo y la Torre de David. En el lado inferior, a la izquierda, se advierte una construcción amurallada, que posiblemente represente el huerto cerrado.

Este marco permite atribuir la obra a Miguel González, pues es muy parecido al de una Virgen de Guadalupe de dicho artista de Los Angeles County Museum of Art (fig. I2). Ambos coinciden en la factura. El marco de la Virgen de Guadalupe posee 16 guirnaldas que contienen los nombres de María, alternadas con flores esquematizadas de pétalos multicolores. Esta obra, como la anterior, muestra en el lado superior a la derecha el sol y en el inferior el pozo y la fuente, así como el espejo en el larguero izquierdo. Tanto la escalera como la palmera y un motivo arquitectónico — al parecer, la Torre de Davidaparecen en el larguero izquierdo, mientras que la Alegoría de la Encarnación los muestra en el derecho y, en el caso de la escalera, en el lado superior. Las similitudes no sólo sugieren una autoría común, sino también que el diseño resultó exitoso en este tipo de marcos. ${ }^{80}$

77. Ramos Sosa, op. cit., p. 2 I4.

78. Jean Claude Bonne, "Les Ornaments de l'histoire (à propos de l'ivoire carolingien de Saint Remi)", Annales HSS, 5i/I, 1996, p. 40. Esto es digno de reflexión, pues sugiere que también las figuras integrantes del repertorio habitual podrían poseer cierto simbolismo.

79. Estas azucenas son muy similares a las que rodean la Tota Pulchra pintada en un muro del claustro bajo del convento franciscano de Huejotzingo, en Puebla.

8o. Hay diseños parecidos en numerosos modelos europeos. Véase un ejemplo novohispano en Elisa Vargaslugo et al., Juan Correa, su vida y su obra. Repertorio pictórico, Segunda parte, t. IV, México, Universidad Nacional Autónoma de México-Instituto de Investigaciones Estéticas, I99I, fig. I. 


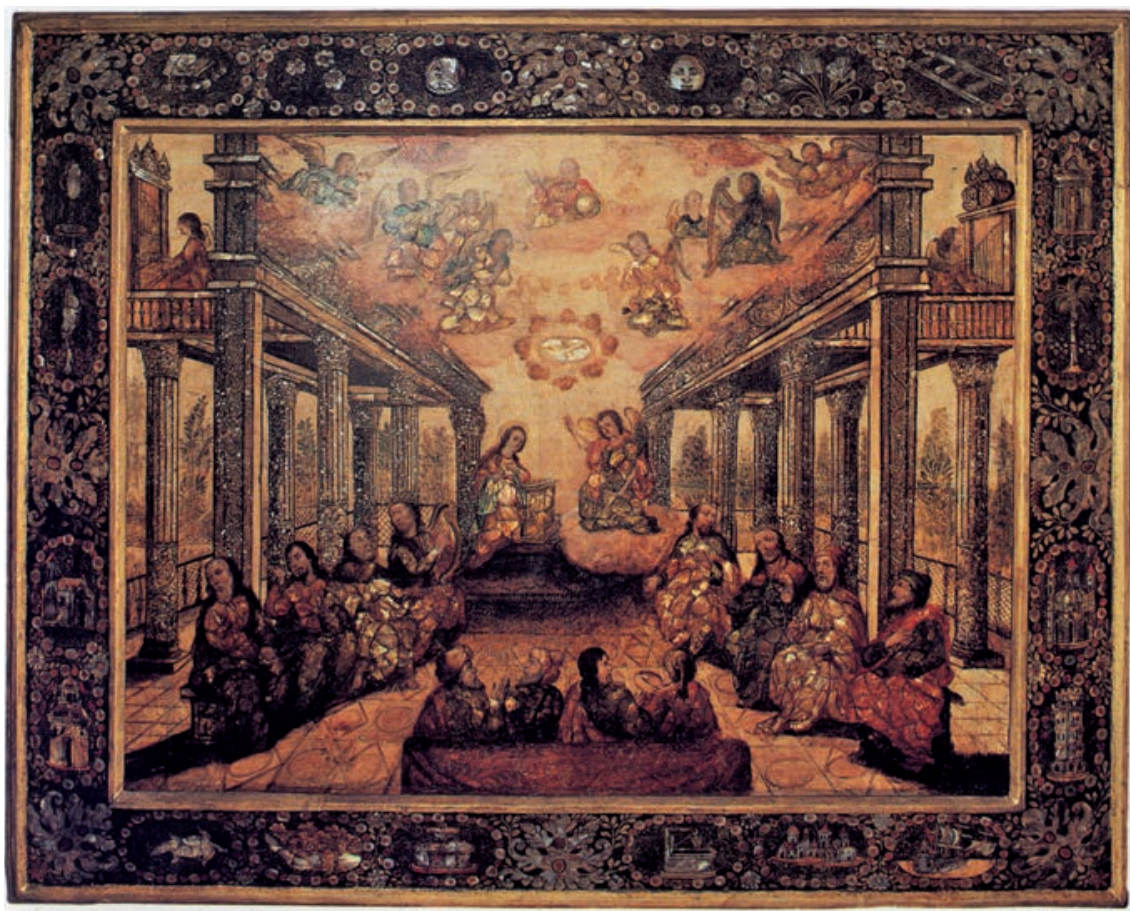

I I. Anónimo, Alegoría de la Encarnación, finales del siglo XVII-principios del siglo XVIII, ¿óleo y temple? e incrustaciones de concha nácar sobre tabla, IOO x I25 cm. Hermandad y Archicofradía de los Nazarenos del Dulce Nombre de Jesús, Sevilla, España. Imagen tomada de Ramos Sosa, op. cit. (vid. supra n. 74), p. 215.

\section{La órbita de los González. Las series religiosas anónimas}

Aquí se comentarán tres series religiosas anónimas cuya factura permite afirmar que son de los González, aunque de momento no sea posible determinar con certeza a cuál de ellos corresponde. Se trata de una serie de 24 tablas de la Vida de Cristo (figs. 7 y I3-I5), así como una de al menos iI que hasta hace poco se creyó de seis (fig. I8) y otra de I2 tablas de la Vida de la Virgen (figs. I7 y I9) denominadas, respectivamente, Serie I y Serie II. Todas se conservan en el Museo de América y exhiben esmero tanto en el uso de la concha 


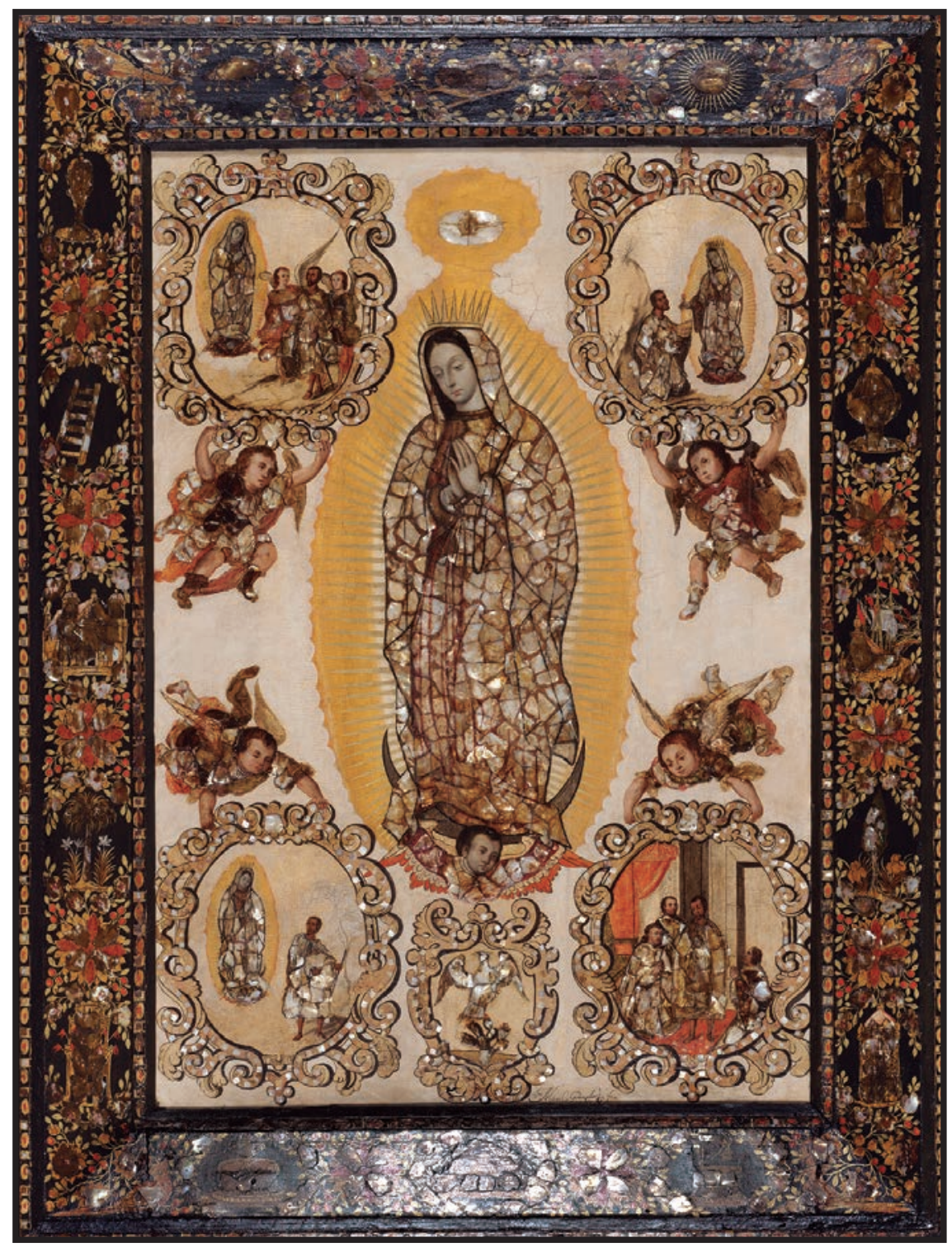

I2. Miguel González, Virgen de Guadalupe, finales del siglo xvII-principios del siglo XVIII, ¿óleo y temple? e incrustaciones de concha nácar sobre tabla, I24.46 × 95.25 cm. Los Angeles County Museum of Art. Digital image (C) 2013. Museum Associates/LACMA. Licensed by Art Resource, New York. 
como en la capa de pintura que la cubre, además de acusados intereses ornamentales. Las dos series de la Vida de la Virgen son muy parecidas. ${ }^{8 \mathrm{I}}$ Esto es significativo, pues no hay duda de que los González hicieron muchas versiones del tema. También la serie de la Vida de Cristo y la de la Vida de la Virgen I exhiben ciertas similitudes, y por ello aquí exploraré la posibilidad de que todas procedan del mismo taller.

Si bien la identificación de los modelos aún está pendiente, al parecer las tres series tomaron distintos elementos de varias fuentes. Tanto la Vida de Cristo como la Vida de la Virgen II exhiben fragmentos grandes y regulares de nácar dispuestos a modo de mosaico en las vestiduras de los personajes principales —algo ajeno a las obras firmadas que se conocen. Las transparencias de la capa pictórica son especialmente logradas en dichas series. Por otro lado, los marcos de la Vida de Cristo y la Vida de la Virgen I son virtuosos y la Vida de la Virgen II destaca por la ornamentación de las escenas.

En la serie de la Vida de Cristo, el nácar exhibe un brillo notable bajo la túnica azul de Jesús, lo que le otorga una belleza excepcional. Dicho color es difícil de emplear, ${ }^{82}$ y rara vez aparece en estas obras. Por ejemplo, está casi ausente de las series de la Vida de la Virgen, que sin embargo destinan los colores más intensos (el verde y el rojo) a los personajes principales. La técnica pictórica revela familiaridad con este tipo de trabajos, pues la mayoría de los fragmentos de concha conservan la capa pictórica original —algo poco frecuente, por la fragilidad de las obras.

García Sáiz ha advertido que la serie de la Vida de Cristo es "un trabajo de taller en el que cada cuadro es concebido con total individualidad. Por esta razón los personajes principales de la narración no responden a un modelo único". ${ }^{83}$ Los rostros de belleza notable son escasos. En las tablas Jesús con la cruz a cuestas y Jesús ante Pilatos, el rostro de Jesús es mucho más virtuoso que la mayoría de los rostros de esta serie. La desigualdad es tan pronunciada que tiene sentido preguntarse si el artista director del taller pintó el rostro de

8ı. Cfr. María Concepción García Sáiz, "Vida de la Virgen”, en Los siglos de oro..., op. cit., p. 377 .

82. Según Francisco Pacheco, el azul es el color "más delicado y más dificultoso de gastar y a muchísimos pintores buenos se les muere”. Cfr. F.J. Sánchez Cantón (prel., notas e índices), Arte de la pintura, Madrid, Instituto de Valencia de Don Juan, t. II, libro tercero, cap. V, I956, pp. 84-85. Agradezco a Patricia Díaz Cayeros haber llamado mi atención a este comentario de Pacheco.

83. María Concepción García Sáiz, "Vida de Cristo", en Los siglos de oro..., op. cit., p. 374. 
Jesús en todas las tablas. ${ }^{84}$ Quizá haya habido poco tiempo para terminar el trabajo y los rostros de los personajes secundarios sean obra de los oficiales. En cualquier caso, dado el esmero del trabajo pictórico sobre la concha y la ornamentación, las diferencias de factura de los rostros sugieren que no se consideraron lo más importante de las obras.

Por otro lado, se advierte el parecido entre la Adoración de los pastores de esta serie (fig. I3) y las Natividades de Juan y Miguel González, ya comentadas (figs. I y 2). El parecido es aún más notable con una Adoración del Niño Jesús anónima que se halla en la parroquia de Tlazoyaltepec, en Oaxaca. ${ }^{85} \mathrm{Am}-$ bas muestran a la izquierda del espectador, como escena secundaria, la aparición del ángel a los pastores. También el pesebre y el pastor que aparece a la izquierda cargando un cordero sobre los hombros son muy parecidos en los dos casos. ${ }^{86}$ No obstante, las obras exhiben también variaciones, pues en la correspondiente a la serie de la Vida de Cristo María y José se hallan a ambos lados de Jesús, rodeados de los pastores y de los animales del establo, que aparecen al centro de la composición. El buey observa la escena, mientras el asno se vuelve a comer el heno que se encuentra en el muro situado detrás. Por su parte, la tabla oaxaqueña muestra a María y José a la derecha y a los tres pastores a la izquierda. Dicha tabla omite al asno y sitúa al buey en primer plano, a la derecha del espectador.

Esta obra exhibe como escena secundaria a la derecha del espectador una Adoración de los magos muy parecida a la versión de la serie de la Vida de Cristo aquí comentada. Ambas muestran a los magos y su comitiva al momento de su encuentro con Jesús. Aunque la tabla oaxaqueña comprime la escena, las dos

84. Según Vicente Carducho: "Y no todas vezes los Mtros se ayudan de los oficiales, que tal vez lo hazen todo por su mano". Cfr. Rocío Bruquetas, Técnicas y materiales de la pintura española en los siglos de oro, Madrid, Fundación de Apoyo a la Historia del Arte Hispánico, 2002, p. 77.

85. La obra se dio a conocer en García Lascurain Vargas, op. cit., p. 25 I. La autora advirtió: "En la escena de los pastores al lado del pesebre se observan ciertos rasgos parecidos a los de un enconchado sobre el mismo tema perteneciente a la Gellatly Collection de la Smithsonian Institution de Washington, obra firmada por Juan González en I662: los rostros de los personajes, la imagen del Nińo Jesús, algunos detalles en la arquitectura, la canasta depositada al frente, la cuna del pesebre con paja y la cabeza del buey que acompańa el conjunto muestran dicha semejanza". Cfr. p. 254.

86. Este personaje aparece, con variaciones, en numerosos modelos de la época. Por ejemplo, en una Adoración de los pastores de Giovanni Battista Trotti, il Malosso (I555-I6I9), subastada en Sotheby's de Londres el 9 de julio de 2003 . Véase una imagen en www.artvalue.com. 


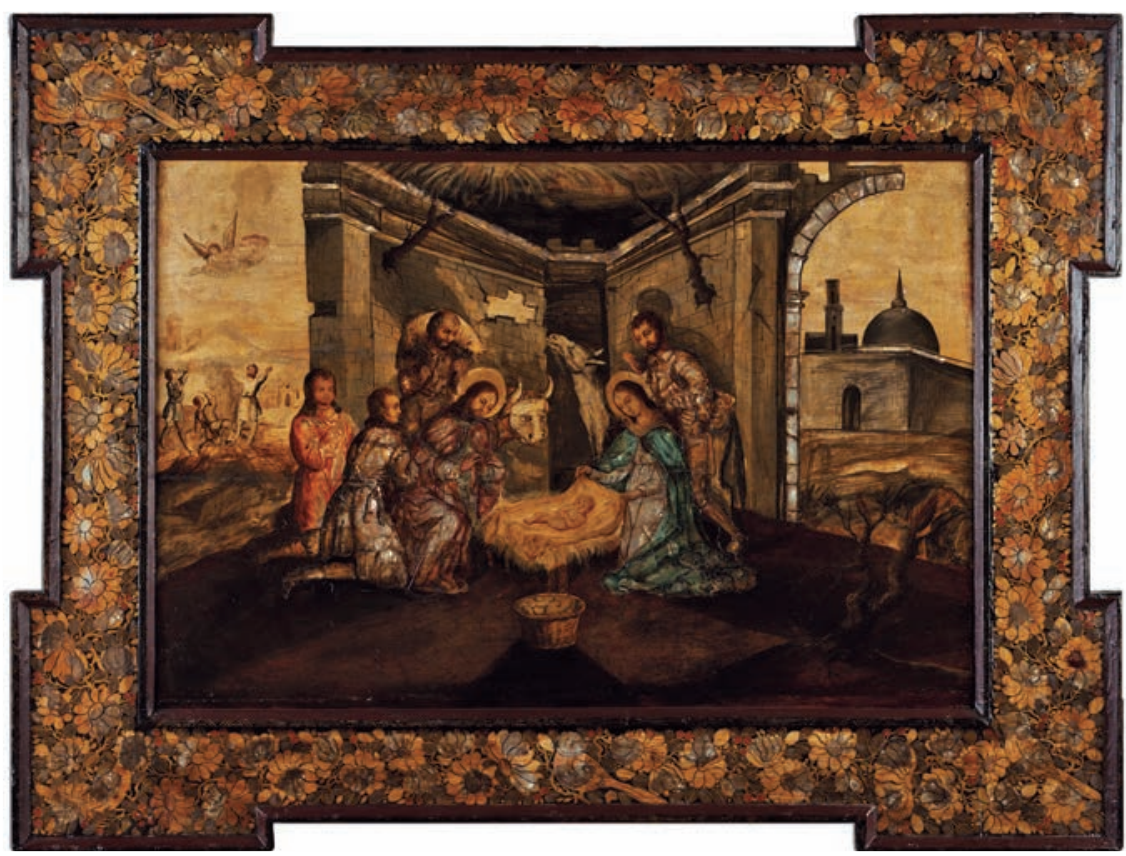

I3. Anónimo, Adoración de los pastores, de la serie Vida de Cristo, finales del siglo XviI-principios del siglo XVIII, ¿̇óleo y temple? e incrustaciones de concha nácar sobre tabla, $69 \times$ I02 $\mathrm{cm}$. Museo de América, Madrid, núm. de inv. oor37.

se informan en modelos similares. Ahora bien, tanto los rostros como el trabajo pictórico sobre los fragmentos de nácar son más virtuosos en la tabla de la serie de la Vida de Cristo. Sin embargo, la desigualdad de factura de los González permite considerar la posibilidad de que las dos tablas hayan sido obra del mismo artista.

Dado que algunas tablas de la serie de la Vida de Cristo son muy parecidas a las Alegorías del Credo de Miguel González, resulta tentador atribuir a este artista la serie de la Vida de Cristo. Sin embargo, conviene recordar que en ocasiones el trabajo de Miguel y Juan González muestra notables coincidencias. Por otro lado, el uso virtuoso del azul sobre las incrustaciones regulares de concha de la Vida de Cristo es ajeno a las obras firmadas y, al parecer, el uso de una paleta rica es más habitual en Juan González. ${ }^{87}$ Más aún, las series de numerosas tablas pueden haber involucrado a distintos artistas. Así pues, si bien es 
muy probable que Miguel González haya intervenido en la serie de la Vida de Cristo, no se debe descartar la participación de su pariente Juan.

El Bautismo de Jesús (fig. I4) destaca por la atención a los detalles y el esmero en el paisaje, pues hay numerosos árboles de troncos muy delgados y retorcidos que lucen pequeñas ramas secas. Algunos exhiben cierto follaje verde, ligeramente sombreado. En contraste, otras partes de la tabla parecen inacabadas. Por ejemplo, las vestiduras de Jesús — sostenidas por el ángel situado junto a Juan - muestran los trazos que la delinean, pero carecen de incrustaciones de concha y de capa pictórica. Recuérdese que la misma apariencia inacabada se halla en algunas figuras de la serie de la Conquista de México hecha por ambos González (fig. Io), lo cual sugiere que también esta serie de la Vida de Cristo está ligada a ellos.

Esta pintura es muy parecida a una versión anónima del mismo tema de la Hispanic Society of America de Nueva York. ${ }^{88}$ La tabla de la serie es apaisada, mientras que la neoyorquina es de formato vertical y de composición más sencilla. Ahora bien, tanto el estudio anatómico como los rostros de Jesús y Juan son extremadamente parecidos en ambas. En la obra neoyorquina la capa pictórica que cubría el nácar se ha desprendido, dejando a la vista las formas y tamaños irregulares de los luminosos fragmentos del material. Pese al deterioro, se advierte la buena calidad del trabajo original, pues las partes en que la capa pictórica se mantiene íntegra revelan la factura de un pintor experimentado. Esta obra muestra a la izquierda del espectador a dos personajes. Uno de ellos recuerda al ángel que en la tabla madrileña aparece a la derecha del espectador, atestiguando el bautismo. Como se señaló, dicha obra incluye numerosos árboles, mientras que la neoyorquina exhibe sólo uno, detrás del Bautista, hecho de numerosos fragmentos de concha de formas regulares. La pérdida de la capa pictórica impide saber si el tratamiento original fue similar al de la otra pintura, aunque la calidad del trabajo conservado sugiere que sí. Más allá del uso de un modelo común, el extremo parecido de la factura sugiere que proceden del mismo taller. Sin embargo, para tener mayor certeza al respecto es necesario hacer estudios técnicos.

Por otro lado, es interesante comparar la versión de Las bodas de Caná de la serie de la Vida de Cristo (fig. I5) y la de Nicolás Correa, de I696, conservada en la Hispanic Society of America (fig. I6). Las dos se basan en modelos similares, pero la obra de Correa despliega recursos ténicos que le dan una rique- 


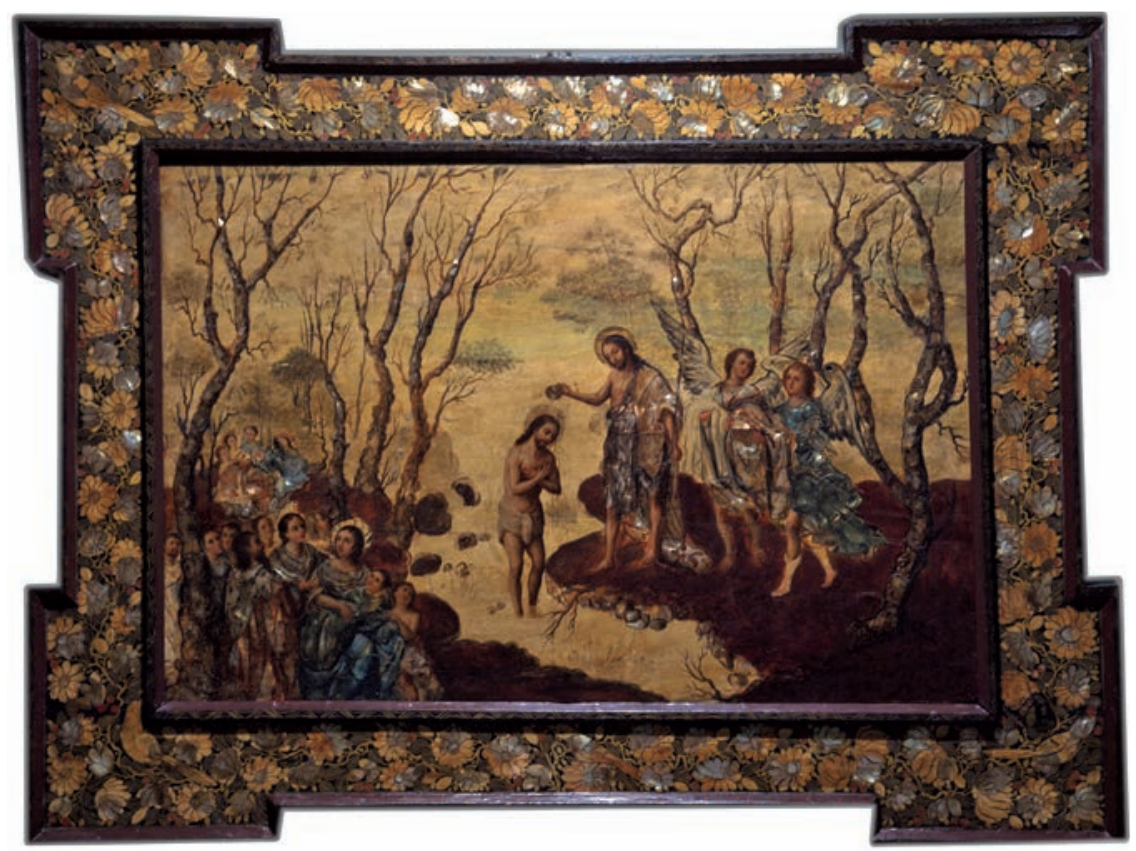

I4. Anónimo, Bautismo de Jesús, de la serie Vida de Cristo, finales del siglo xviI-principios del siglo xviII, ¿̨óleo y temple? e incrustaciones de concha nácar sobre tabla, $69 \times 102 \mathrm{~cm}$. Museo de América, núm. de inv. oor4I.

za particular. En ambos casos, aparecen en primer plano Jesús y María. Ella está de pie, casi al centro de la composición y se dirige a su hijo, que preside la mesa del banquete nupcial por una de sus cabeceras, mientras los contrayentes ocupan la opuesta. La mesa está dispuesta en diagonal y Jesús se sitúa a la derecha de la composición. Tanto Jesús como María y los novios son extremadamente parecidos en ambas tablas.

Las dos obras muestran en primer plano a un par de criados sirviendo el vino directamente sobre el piso y, a un costado, una escena secundaria en la que se advierte el trajín de la cocina. La mesa está protegida por un cortinaje rojo y próximo al mueble se halla un mostrador. Ahora bien, en la tabla de la serie tanto los criados que sirven el vino como la escena secundaria se encuentran a la izquierda, mientras el mostrador se ubica al centro, justo detrás de los contrayentes. Por su parte, la obra de Correa muestra a los criados sirviendo 


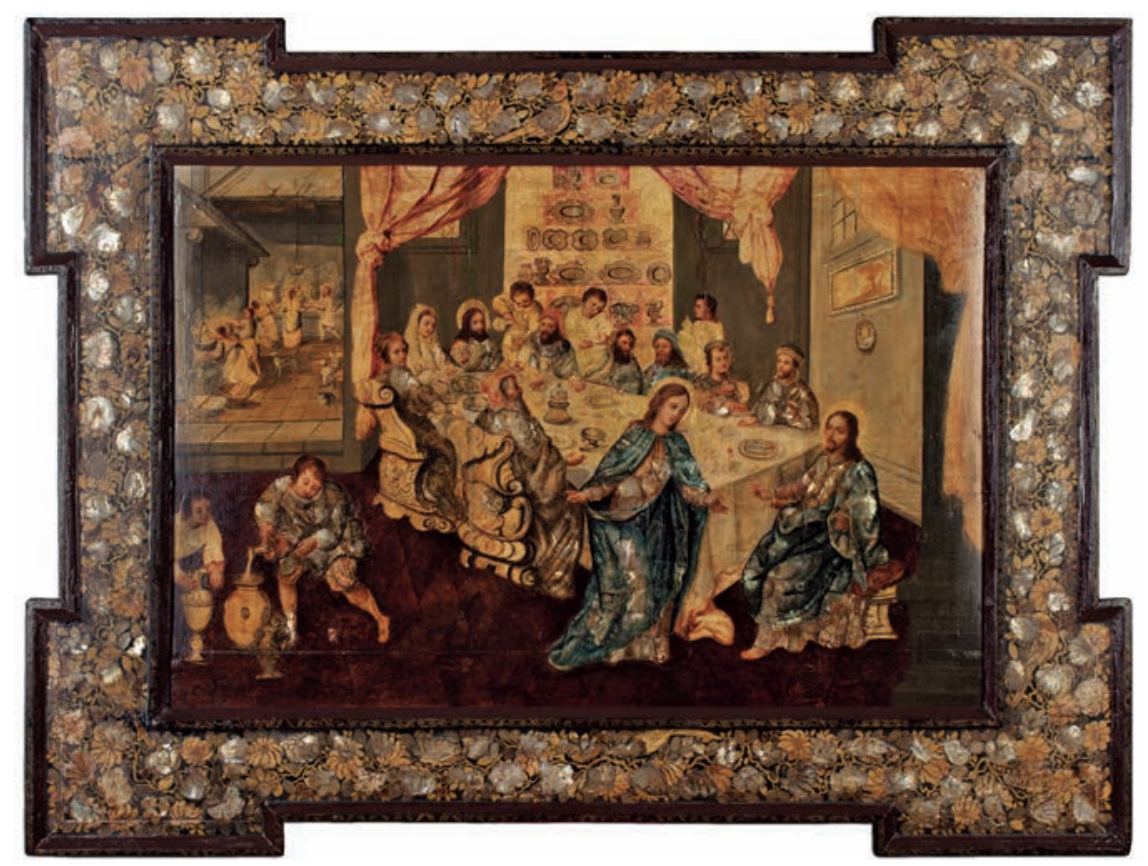

I5. Anónimo, Las bodas de Caná, serie de la Vida de Cristo, finales del siglo xvir-principios del siglo XVIII, ¿̇óleo y temple? e incrustaciones de concha nácar sobre tabla, $69 \times 102 \mathrm{~cm}$. Museo de América, núm. de inv. oor 43.

el vino sobre el piso a la derecha, mientras que a la izquierda se halla otro par de criados sirviéndolo sobre una mesa situada delante del mostrador. En este caso, la cocina se encuentra a la derecha y el cortinaje rojo que cubre la mesa es parte de un rico dosel.

La tabla del Museo de América reserva el nácar casi exclusivamente a las vestiduras de los personajes. El azul de las túnicas de Jesús y María resulta muy llamativo, a pesar de que en la paleta predominan el amarillo y el café rojizo. Sin embargo, la obra de Correa es más rica debido al contraste entre el fondo negro y el brillo de los numerosísimos fragmentos de concha que simulan un piso marmoleado, una vajilla de plata en el mostrador de la izquierda y dos marcos en el muro negro del fondo. Todas estas figuras están hechas de fragmentos de concha y prescinden de capa pictórica. Los marcos parecen estar vacíos, algo desconcertante en una obra que, por lo demás, se interesa mu- 


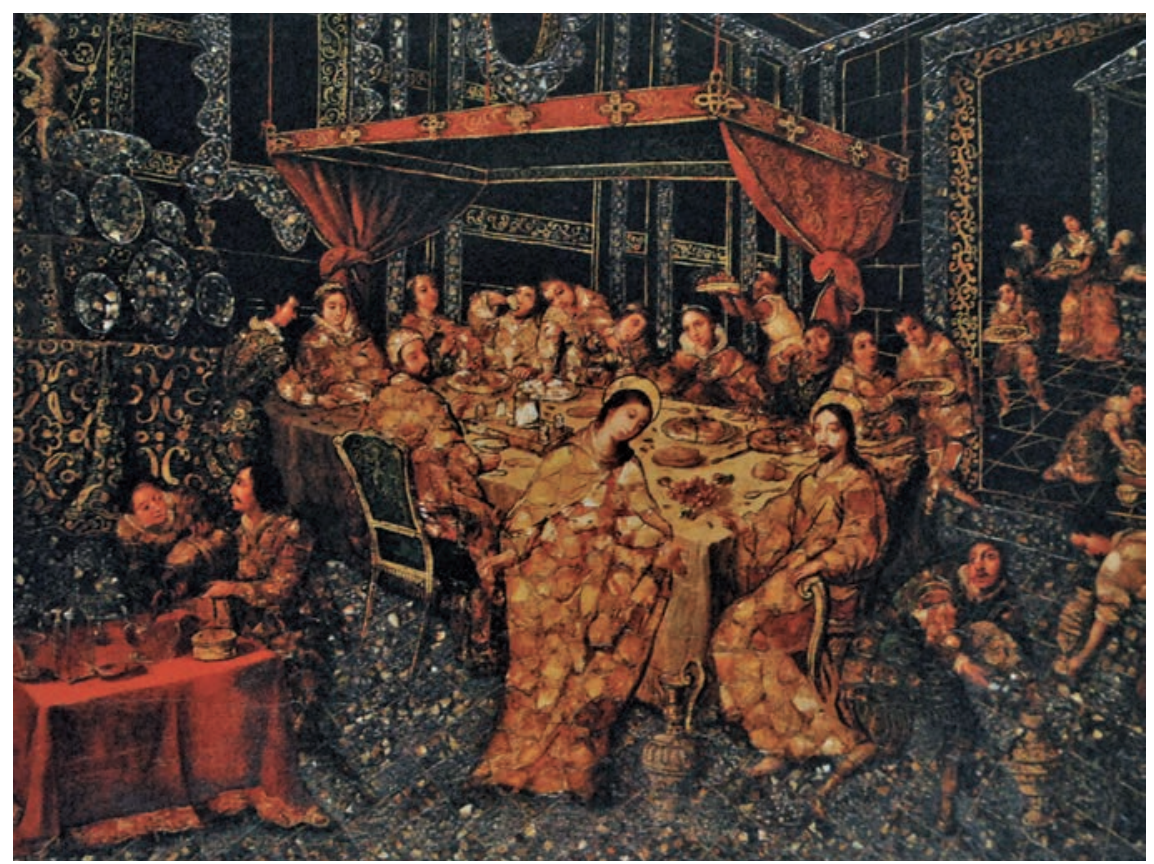

I6. Nicolás Correa, Las bodas de Caná, I696, ¿̨óleo y temple? e incrustaciones de concha nácar sobre tabla, $57.6 \times 74.8 \mathrm{~cm}$. Hispanic Society of America de Nueva York. Imagen tomada del catálogo Revelaciones: Las artes en América Latina, op. cit. (vid. supra fig. 3), p. I23.

cho por los detalles. Esto resulta aún más llamativo si se tiene en cuenta que la tabla de la serie de la Vida de Cristo incluye en el muro, a la derecha del espectador, una ventana bajo la cual cuelgan un paisaje y un pequeño cuadro en forma de medallón.

Al usar la concha desprovista de pintura para enmarcar elementos secundarios de su obra, Correa juega con el espectador, atrayendo momentáneamente la atención a la periferia para después devolverla a la escena principal, reforzando así su importancia. A la vez, el vacío de los marcos facilita hallar el camino de regreso a la representación religiosa. De esta manera, Correa aprovechó las posibilidades lumínicas del nácar para embellecer la obra y, al mismo tiempo, destacar su tema sagrado. Si bien no es posible hacer afirmaciones sobre el supuesto vínculo entre los González y los Correa, el dominio técnico que hacia 1690 exhibían tanto Nicolás Correa como Miguel y Juan González 
difícilmente habría sido una coincidencia. Aunque los tres talleres funcionaron de manera independiente, la creación de Nicolás Correa de obras notables en esa época demuestra que la producción rebasó el ámbito familiar de los González desde una etapa relativamente temprana.

Por su parte, la Vida de la Virgen II no sólo llama la atención por los fragmentos grandes y regulares de nácar en las vestiduras de María, que mantienen su brillo bajo la capa pictórica, sino también por la delicadeza de algunos rostros y el interés en el paisaje (figs. I7 y I9). Pocas obras firmadas exhiben rostros virtuosos, lo que confirma la capacidad de los González de introducir variaciones a un trabajo cuya aparente homogeneidad se desdibuja si se tiene en cuenta un buen número de ejemplares. Respecto a esta serie, García Sáiz ha advertido:

Aparentemente todas [las tablas] formaban parte de un mismo conjunto, de idénticas medidas y con un empleo de la técnica del "enconchado" similar. Sin embargo, no se trata de un conjunto unitario [pues] son muy numerosas las diferencias que se detectan en la manera de resolver las composiciones [...] [se puede] advertir con claridad el uso de diferentes modelos para la representación de los mismos personajes, y un tratamiento del espacio y de los volúmenes poco uniforme, alternando las figuras esbeltas, de ademanes delicados, con otras de canon más achaparrado, envueltas en ropajes más voluminosos, que contribuyen a acentuar la sensación de pesadez. Todo ello nos habla de un trabajo de taller, en el que intervienen varias manos que actúan con demostrada independencia. ${ }^{89}$

Coincido con García Sáiz en que las diferencias derivan, en parte, de la intervención de varios miembros del taller, del uso deliberado de distintos modelos y de la inclusión en la serie de tablas muy numerosas hechas posiblemente para el mercado abierto. Por otro lado, las tablas La presentación de la Virgen al templo y Los desposorios de la Virgen son muy similares tanto en la Serie I como en la II. En el primer caso (figs. I7 y I8), ambas muestran a Joaquín y Ana en primer plano a la derecha, mirando a María subir las escaleras hacia el lado opuesto, en dirección al rabino - cuyo rostro es muy similar en ambos casos- que le extiende las manos, anticipando el encuentro. En la Serie I su único acompañante es un hombre joven de gesto solemne, mientras que en la Serie II se advierte un grupo numeroso de hombres y mujeres, cuyos rostros exhiben distintas expresiones. 


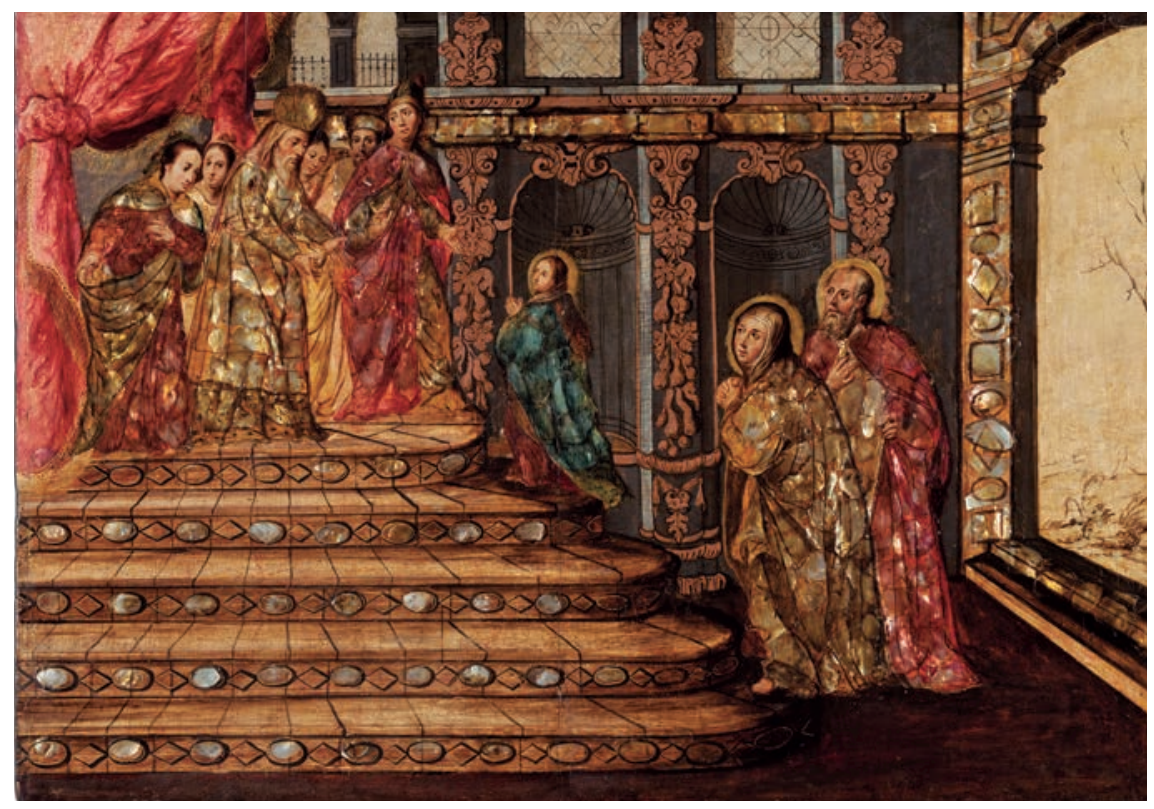

17. Anónimo, Presentación de la Virgen en el templo, serie de la Vida de la Virgen II, finales del siglo XVII-principios del siglo XVIII, ¿̇óleo y temple? e incrustaciones de concha nácar sobre tabla, $97 \times 68 \mathrm{~cm}$. Museo de América, Madrid, núm. de inv. 00132 .

En las dos obras, el área donde se halla el rabino muestra un cortinaje rojo en el ángulo superior, a la izquierda. La tabla de la Serie I incluye ahí también una columna toscana. El interior de la sinagoga es muy similar en ambos casos, pues sólo varían ciertos detalles ornamentales. El trabajo es más esmerado en la Serie II, que llama la atención por su paleta contrastada, así como por la riqueza de la arquitectura. Especialmente lograda resulta la túnica azul de la Virgen, que permite advertir la luminosidad del nácar subyacente. Es decir, el protagonismo de la figura principal se manifiesta, en parte, por el uso del color.

La tabla muestra a la derecha una puerta que da paso a un sencillo paisaje donde se advierte un árbol. Su tronco está trazado con finas líneas oscuras cuyo esmero demuestra que el autor le prestó mucha atención. Numerosas tablas de esta serie destacan por su interés en el paisaje, pero quizá donde resulta más evidente es en el Abrazo ante la puerta dorada (fig. I9). A ambos lados del abrazo, situado al centro de la composición, se despliegan sendas esce- 


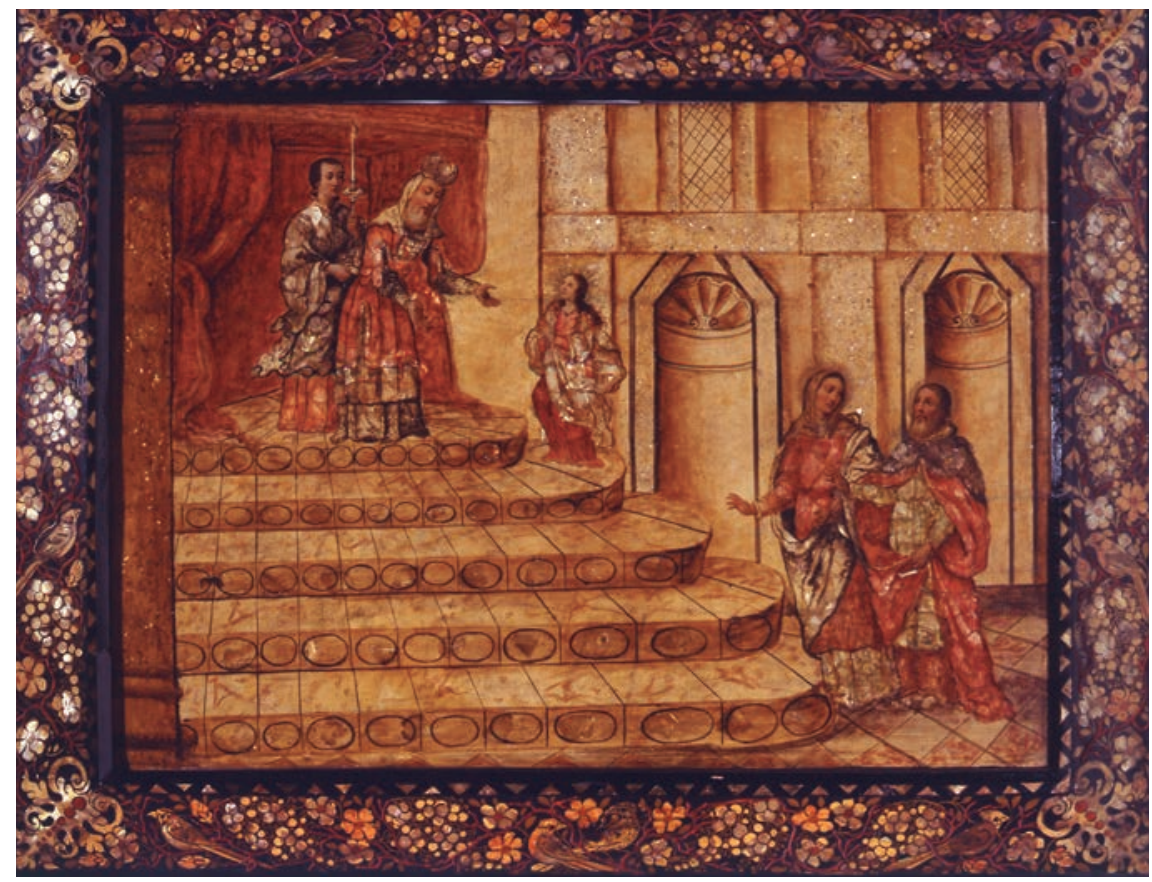

I8. Anónimo, Presentación de la Virgen en el templo, serie de la Vida de la Virgen I, finales del siglo XVII-principios del siglo XVIII, ¿̨óleo y temple? e incrustaciones de concha nácar sobre tabla, 6I × $86 \mathrm{~cm}$. Museo de América, Madrid, núm. de inv. ooi7I.

nas secundarias que muestran por separado a Joaquín y Ana cuando el ángel los llama a encontrarse en la puerta dorada. Joaquín se halla a la izquierda del espectador, ocupándose de su rebaño, mientras que Ana aparece a la derecha. Las soluciones del paisaje son muy distintas en ambos casos, pues el artista las varió para hacer gala de su capacidad artística.

En el primer plano, así como en las escenas secundarias, hay troncos que muestran abundantes fragmentos irregulares de concha. La solución aumenta la luminosidad derivada de la rica ornamentación de la puerta dorada. A la izquierda, los árboles exhiben troncos esbeltos y el follaje muestra una pincelada muy suelta. Destaca la virtuosa factura de los corderos, apenas esbozados con toques de pincel. En contraste, a la derecha, tanto el paisaje como las figuras muestran tonos sepia y un tratamiento que recuerda las aguadas. Aun así, el 


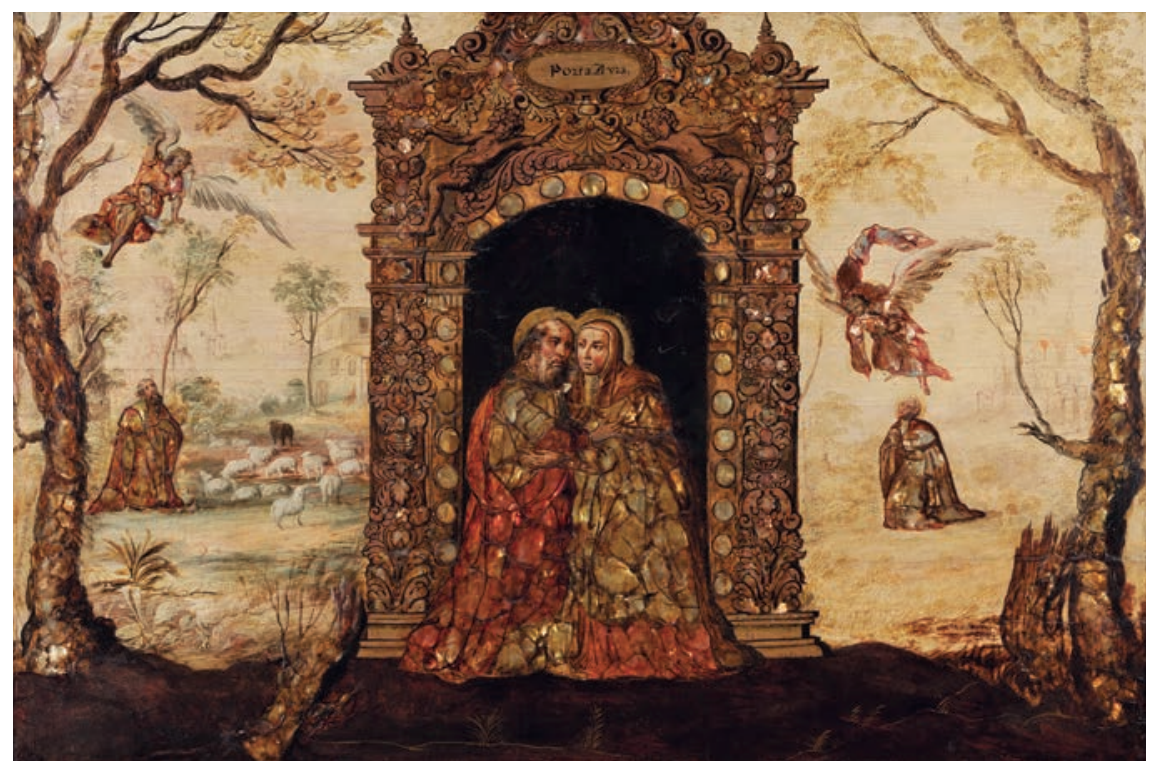

19. Anónimo, Abrazo ante la puerta dorada, serie de la Vida de la Virgen II, finales del siglo XVII-principios del siglo xviII, ¿óleo y temple? e incrustaciones de concha nácar sobre tabla, $97 \times 68 \mathrm{~cm}$. Museo de América, Madrid, núm. de inv. oor7o.

follaje está pintado con esmero. Este paisaje resulta un poco menos llamativo que el del lado opuesto, pero el contraste entre ambos parece obedecer al empeño del artista en experimentar con soluciones distintas, no a la intervención de diferentes miembros del taller. En mi opinión, ambos paisajes revelan mucha familiaridad con los modelos y soluciones europeos y su esmero sugiere que el público novohispano los tuvo en gran estima en este tipo de pinturas.

Por otro lado, si bien las tablas de esta serie exhiben diferencias estilísticas notables, los oficiales y aprendices difícilmente habrían tenido libertad para introducirlas por su cuenta. Dichas variaciones deben haber sido determinadas por el artista al frente del taller y no necesariamente obedecen a que la serie se haya encargado a dos pintores. En este caso la autoría es difícil de precisar, pues el uso de una paleta relativamente contrastada y el interés por la naturaleza la acercan al Francisco Xavier embarcándose hacia Asia (fig. 3) de Juan González. Ahora bien, el esmero en la representación de los rostros resulta más habitual en el trabajo de Miguel González, lo mismo que la tendencia a introducir 
ciertas variaciones respecto a los modelos. Por otro lado, la serie de la Vida de la Virgen I cuyo parecido con la serie que aquí nos ocupa ya se mencionó posee marcos similares a los de la serie de la Vida de Cristo, en la cual casi con seguridad intervino Miguel González. Así pues, es probable que también ese artista se haya involucrado en la serie de la Vida de la Virgen II.

A diferencia de la serie arriba comentada, la Vida de la Virgen I posee unidad estilística y un solo modelo para los personajes principales. La paleta es poco contrastada, con predominio del amarillo, y las incrustaciones de concha son pequeñas e irregulares, aunque muy luminosas. Dicha luminosidad, junto con los ricos marcos, da a las tablas la mayor parte de su atractivo. Quizá esta serie haya sido un encargo destinado a Felipe V, pues su inventario de bienes de 1747 se refiere a las obras como "onze [tablas] de 3/4 de caída y vara de ancho con marcos de perlas embutidos en nacar [...] echura de Yndias". ${ }^{\circ}$ Llama la atención que el documento sólo mencione el nácar al referirse a los marcos, no a las escenas, pues también están incrustadas de dicho material. Acaso el tasador haya advertido la sencillez de las escenas, mientras que los marcos lucen un llamativo abigarramiento de flores, hojas, aves y racimos de uvas. ${ }^{9 \mathrm{I}} \mathrm{El}$ parecido con los marcos de la serie de la Vida de Cristo es notable, excepto porque los de esta última omiten los racimos de uvas y varían la solución de las aves, sobre todo en la cabeza..$^{92}$ Como los marcos de estas pinturas suelen presentar variaciones, las similitudes entre ambas series sugieren que pueden haber sido obra del mismo artista.

Por otro lado, las tablas Presentación de la Virgen al templo, Los desposorios de la Virgen y Sueño y arrepentimiento de José usan los mismos modelos y poseen una factura similar a la serie de la Vida de la Virgen II. Esto sugiere que ambas proceden del mismo taller — lo cual podría confirmarse más adelante mediante estudios técnicos. En cualquier caso, las tres series destacan por la regularidad de los fragmentos de concha, así como por el trabajo pictórico

90. Agradezco a María Concepción García Sáiz haberme informado que esta serie corresponde a dicho lote, mencionado en Ángel Aterido Fernández et al., Colecciones de pintura de Felipe Ve Isabel Farnesio: inventarios reales, vol. II, Madrid, Fundación de Apoyo a la Historia del Arte Hispánico, 2004, p. I20. Ocho de estas tablas pertenecen al Museo de América. García Sáiz me informa que una más se ha localizado recientemente en España y se desconoce el paradero de las otras.

91. Véase Ocaña Ruiz, "Los marcos...”, op. cit., p. I 47.

92. Ibidem, p. I 47 . 
sobre ésta y por la ornamentación. Asimismo, el esmero de algunos rostros y paisajes demuestra que son dignas de más reflexión.

\section{Conclusiones}

Las pinturas incrustadas de concha requieren habilidades técnicas particulares y deben haber tenido un origen preciso - los talleres de los Gonzáleza partir del cual se propagaron a otros talleres de pintura. Como se ha visto, su elaboración ya había rebasado el ámbito de dicha familia en la época en que alcanzaron el apogeo. Ahora bien, no hay duda de que el público novohispano tuvo preferencia por el trabajo de los González, quienes quizá fueron los únicos en especializarse en este tipo de pinturas. En parte, su éxito se debió a su minuciosidad, que en las mejores obras incluye tanto el trabajo pictórico como los embutidos de concha y se advierte por igual en las escenas y los marcos.

Lejos de agotar las características del estilo de los González, esta revisión ha mostrado que en ocasiones ambos homogeneizaron deliberadamente su factura y, a la vez, que su trabajo exhibe constantes variaciones, las cuales merecen más estudio. Las series anónimas aquí comentadas se acercan al trabajo conocido de Miguel González, pero el parecido entre algunas de sus pinturas y las de Juan González impide descartar en definitiva la intervención de este último. Si bien la relevancia del trabajo de Miguel González es indiscutible, el de Juan González fue mucho más prolongado y quizá de factura más diversificada. De ahí la necesidad de seguirlo estudiando con cuidado y no apresurarse a hacer atribuciones. En el futuro deberá suponerse que muchos ejemplares deben ser de artistas distintos a los González y afianzar las atribuciones con estudios técnicos, en la medida de lo posible. Más aún, si bien dichas atribuciones son necesarias en relación con una producción mayormente anónima, su importancia es secundaria pues la riqueza de las obras no se agota al atribuirlas a determinados artistas. Antes bien, el mayor reto que plantea su estudio es mirarlas con cuidado, sin encasillar el estilo de sus autores - el cual, en el caso de los González, es de suyo muy difícil clasificar.

Finalmente, conviene subrayar que el trabajo de los González comparte muchos rasgos de otras pinturas novohispanas. Lejos de recibir pasivamente la influencia del arte asiático, estos artistas hicieron una apropiación selectiva de 
ciertos diseños japoneses desde la pintura novohispana. Así pues, para entender mejor sus obras, es necesario profundizar en su carácter pictórico. Como se ha visto, estas pinturas dan cuenta de la creatividad del arte novohispano, pues resultan muy originales pese a compartir los intereses, los recursos y técnicas de otras pinturas de su tiempo. \$

\footnotetext{
* Artículo recibido el 9 de abril de 2012; aceptado el 21 de noviembre de 20 I 2.
} 


\section{APÉNDICE* \\ Listado de obras}

\section{Obras firmadas}

I. Serie de 24 tablas de la Conquista de México. Miguel y Juan González, I698, $97 \times 53 \mathrm{~cm}$. Museo de América, Madrid.

I.I. Manda Cortés echar las naos a pique.

I.2. Corren a caballo y se admiran los embajadores.

I.3. Hácese la Villa Rica.

I.4. Entra Cortés en Zempoala (fig. Io).

I.5. Niévales en el camino.

I.6. Los tlaxcaltecas ofrecen a Cortés diez mil indios y acepta mil.

I.7. Fray Bartolomé de Olmedo bautiza cinco indias.

I.8. El sobrino de Moctezuma recibe a Cortés, le sahuma y regala.

I.9. Entrada de Cortés en México por la calzada de San Antonio Abad.

I.Io. Recibimiento de Moctezuma.

I.I I. Visita Cortés a Moctezuma y reciben a los demás los reyes que le acompañan.

I.I2. Llevan a posentar a Cortés... de los idolos.

I.I3. Coronación del rey de Texcoco y destierro del otro a influencia de Cortés.

I.I4. Ollas de carne de sacrificados para sus sacerdotes.

I.I5. Prisión de Moctezuma.

I.I6. Pedrada y flechazo a Moctezuma.

I.I7. Retirada de los españoles la Noche Triste.

I.I8. Los tlaxcaltecas maltratan a Xicoténcatl.

I.I9. Gánase el gran Cu y derribanse los idolos.

I.20. Hacen prisionero a Cortés los indios.

I.2I. Comen los indios carne de españoles y tienen asco.

I.22. Ahorcan a Xicoténcatl.

I.23. Garcia Holinge prende a Cuaubtémoc.

I.24. Manda Cortés quemar y destrozar los idolos que habian quedado.

* Este apéndice registra todas las obras firmadas y a continuación las obras anónimas atribuidas a los González en este artículo. 
2. Serie de 24 tablas de la Conquista de México. Miguel González, I698, I00 × $54 \mathrm{~cm}$. Al Museo de Bellas Artes de Buenos Aires pertenecen 22 tablas, mientras que las tablas i y is se conservan en una colección particular.

2.I. Llega el capitán Cortés con su armada al puerto de San Juan de Ulúa.

2.2. Manda el capitán Cortés echar las naos a pique.

2.3. Alza todo el ejército por capitán general y justicia mayor al capitán Cortés.

2.4. Trabajan en fabricar la Villa Rica los soldados del capitán Cortés.

2.5. En la entrada de Tlaxcala, le dan los indios tlaxcaltecas tres batallas.

2.6. Trae el capitán Xicoténcatl el mozo diez mil indios de guerra.

2.7. Repártense capitanías de indios guerreros en la sierra de Cholula.

2.8. Camina el capitán general Cortés para la ciudad de México.

2.9. Entra el capitán general Cortés en la gran ciudad de México.

2.IO. Grande y solemne recibimiento que hizo el gran emperador Moctezuma al capitán general Cortés en la entrada de México.

2.I I. Visita el emperador Moctezuma al capitán Cortés en sus aposentos.

2.I2. Visita el capitán general Cortés al emperador Moctezuma.

2.I3. Va el capitán general Cortés con sus capitanes al gran Cu de Tlatelolco.

2.I 4. Manda el emperador Moctezuma a sus capitanes le traigan preso a su sobrino.

2.15. Entra el capitán general Cortés en consejo con sus capitanes y soldados.

2.I6. Soberbia batalla que tuvo el capitán general Cortés dentro de la ciudad de México.

2.17. Envía el capitán general Cortés al emperador Moctezuma a que se asome a una azotea.

2.18. Noche triste y lluviosa, en que salió el capitán general Cortés huyendo.

2.19. Bautizase el señor de Texcoco y es su padrino el capitán general Cortés.

2.20. Después de haber puesto el capitán general Cortés cerco a la ciudad de México entra dando guerra.

2.21. Gran desbarate que tuvo el capitán general Cortés dentro del agua.

2.22. Celada que echó el capitán general Cortés.

2.23. Después de ganado el Cu mayor de Tlatelolco huye el emperador Cuaubtémoc.

2.24. Trae preso el capitán de los bergantines al emperador Cuaubtémoc.

3. Serie de 12 tablas de las Alegorias del Credo. Miguel González, finales del siglo XVII-principios del siglo XVIII, 6I $\times 86 \mathrm{~cm}$. La mitad de la serie pertenece al Instituto Nacional de Antropología e Historia, México, y la otra mitad al Patrimonio Artístico del Banco Nacional de México.

3.I. San Pedro. 
3.2. San Andrés (fig. 6).

3.3. Santiago el Mayor (fig. 2).

3.4. Sagrada familia.

3.5. San Felipe.

3.6. San Bartolomé.

3.7. San Mateo (fig. 8).

3.8. Santo Tomás.

3.9. Santiago el Menor.

3.ro. San Simón.

3.I I. San Judas Tadeo.

3.I2. San Matias.

4. Serie de seis tablas de la Defensa de Viena. Juan González, último tercio del siglo XVII, $208 \times 130 \mathrm{~cm}$. Colección particular, islas Canarias.

4.I. Coronación del rey de Hungría.

4.2. Entrada del gran visir a vista de Viena.

4.3. Conquista y ruina del tabor Leopolstadt.

4.4. Minas y asaltos de los turcos.

4.5. Abertura y derrota de los turcos cerca de Ribaxe y dentro del bosque de Viena. 4.6. Derrota de los turcos y toma del gran estandarte y otros.

5. Serie de Los diez mandamientos. Juan González, finales del siglo XvII, 43.8 $\times 58 \mathrm{~cm}$. Colección particular.

5.I. Alegoria del primer mandamiento. PRAECEPTUM I (fig. 4).

5.2. Alegoría del segundo mandamiento. PRAECEPTUM II.

5.3. Alegoría del cuarto mandamiento. PRAECEPTUM IV.

5.4. Alegoría del décimo mandamiento. PRAECEPTUM X.

6. Serie de ocho tablas de la Vida de san Ignacio de Loyola. Juan González, I697, $47 \times 63 \mathrm{~cm}$. Una tabla pertenece al Museo Pedro de Osma de Lima y las otras se conservan en distintas colecciones particulares.

7. Miguel González, Virgen de Guadalupe, I692, 74 × 57 cm. Museo de América, Madrid.

8. Juan González, Virgen de Balvanera, ca. 1690-1700, $63 \times 42 \mathrm{~cm}$. Museo de América, Madrid. 
9. Juan González, Adoración de los pastores, I662, $32.5 \times 4 \mathrm{I} \mathrm{cm}$. Smithsonian American Art Museum, Washington, D.C. (fig. I).

Io. Miguel González, Virgen de Guadalupe, finales del siglo XviI-principios del siglo XVIII, I2 $4.4 \times 95.2 \mathrm{~cm}$. Los Angeles County Museum of Art (fig. I2).

II. Juan González, San Francisco Xavier embarcándose hacia Asia, I703, II3 × $91.75 \mathrm{~cm}$. Colección particular, México (fig. 3).

I2. Juan González, Adoración de los magos, último tercio del siglo XVII, 84.5 × I26.5 cm. Museo Soumaya.

I3. Juan González, Juicio del conde Guillermo III, I699, II $2 \times 70 \mathrm{~cm}$. Museo Soumaya. La firma de esta obra difiere de la de las otras tablas de Juan González.

I4. Agustín del Pino, Virgen de Guadalupe, ca. I700-1730, $70 \times 50 \mathrm{~cm}$. Museo Franz Mayer, México.

I5. Agustín del Pino, San Ignacio de Loyola, ca. I700-I730, 83.5 × 6I cm. Denver Art Museum, Depósito de la colección Frederick y Jan Mayer, Denver.

I6. Nicolás Correa, Boda de Caná, I696, $57.6 \times 74.8 \mathrm{~cm}$. The Hispanic Society of America, Nueva York (fig. I6).

17. Nicolás Correa, Los cinco señores, I694, $59.5 \times 52 \mathrm{~cm}$. Colección particular, México.

18. Nicolás Correa, El camino del Calvario, Paradero desconocido.

19. Pedro López Calderón, Nacimiento de la Virgen, I723, 86.5 × 102 cm. Colección particular, México.

20. Rodulpho, Virgen de Guadalupe, I675-1725, $84 \times 57 \mathrm{~cm}$. Museo Casa Natal de Jovellanos, Gijón. 


\section{Obras atribuidas}

I. Anónimo, Alegoria de la Encarnación, atribuido a Miguel González, finales del siglo XVII-principios del siglo XVIII, IOO $\times$ I $25 \mathrm{~cm}$. Hermandad y archicofradía de los Nazarenos del Dulce Nombre de Jesús, Sevilla, España (fig. II).

2. Serie de 12 tablas de la Vida de la Virgen. Anónimo, atribuido a Miguel o Juan González, ca. I690-1705, 6I × 86 cm. ca. I690-I710.

2.I. Abrazo ante la puerta dorada (fig. 19).

2.2. Presentación de la Virgen al templo (fig. 17).

2.3. Los desposorios de la Virgen.

2.4. Sueño y arrepentimiento de José.

2.5. San José ante María.

2.6. Aparición de Jesús resucitado ante María.

2.7. Pentecostés.

2.8. Dormición o tránsito de la Virgen.

2.9. Traslado del cuerpo de la Virgen.

2.Io. Asunción.

2.I I. Coronación de la Virgen.

2.I2. Escena evangélica [¿El empadronamiento?]

3. Serie de 24 tablas de la Vida de Cristo. Anónimo, atribuido a Miguel o Juan González, finales del siglo XVII-principios del siglo XVIII, $69 \times 102 \mathrm{~cm}$.

3.I. Adoración de los pastores (fig. I3).

3.2. Adoración de los reyes.

3.3. La circuncisión.

3.4. Presentación en el templo.

3.5. Bautismo de Jesús (fig. I4).

3.6. Tentaciones de Cristo.

3.7. Las bodas de Caná (fig. I5).

3.8. La tempestad calmada.

3.9. Jesús comiendo con la pecadora arrepentida.

3.IO. Jesús andando sobre las aguas.

3.I. La transfiguración (fig. 7).

3.I 2. La entrada en Jerusalén.

3.13. La purificación del templo.

3.I4. La última cena.

3.15. La oración en el huerto. 
3.16. El prendimiento.

3.17. Jesús ante el sumo sacerdote.

3.I8. Jesús atado a la columna.

3.19. Jesús escarnecido por los soldados.

3.20. Ecce Homo.

3.21. Jesús ante Pilatos.

3.22. Jesús con la cruz a cuestas.

3.23. La lanzada o crucifixión.

3.24. La resurrección.

4. Serie de la Vida de la Virgen. Anónimo, atribuido a Miguel o Juan González, finales del siglo XVII-principios del siglo XVIII, $97 \times 68 \mathrm{~cm}$. Se conocen ocho tablas que se hallan en el Museo de América de Madrid y se sabe de otras tres cuyo paradero es desconocido.

4.I. Abrazo ante la puerta dorada.

4.2. Presentación de la Virgen en el templo (fig. I8).

4.3. Anunciación.

4.4. Desposorios de la Virgen.

4.5. Sueño y arrepentimiento de José.

4.6. Petición de posada.

4.7. Asunción.

4.8. Inmaculada Concepción. 